\title{
Comparative effects of high oleic acid vs high mixed saturated fatty acid obesogenic diets upon PUFA metabolism in mice ${ }^{\text {it }}$
}

\author{
Matthew J. Picklo, Sr. ${ }^{\mathrm{a}, \mathrm{b}, *}$, Joseph Idso ${ }^{\mathrm{a}}$, Drew R. Seeger ${ }^{\mathrm{c}}$, Harold M. Aukema ${ }^{\mathrm{d}}$, Eric J. Murphy ${ }^{\mathrm{c}}$ \\ a USDA-ARS Grand Forks Human Nutrition Research Center, 2420 2nd Avenue North, Grand Forks, ND 58203-9034, USA \\ b Department of Chemistry, University of North Dakota, Grand Forks, ND 58201, USA \\ ${ }^{\mathrm{c}}$ Department of Basic Sciences, University of North Dakota School of Medicine, USA \\ a Department of Human Nutritional Sciences, University of Manitoba, Winnipeg, MB, Canada R3T 2N2
}

\section{A R T I C L E I N F O}

\section{Keywords}

Oleic acid

Polyunsaturated fatty acid

Oxylipin

Obesity

Linoleic acid

Alpha-linolenic acid

\begin{abstract}
A B S T R A T
Emerging evidence indicates that the fatty acid composition of obesogenic diets influences physiologic outcomes. There are scant data regarding how the content of non-essential fatty acids like monounsaturated fatty acids (MUFA) and saturated fatty acids (SFAs) impact the metabolism of polyunsaturated fatty acids (PUFAs). In this work, we tested the hypothesis that obesogenic diets enriched in oleic acid (OA; 18:1n-9) reduce polyunsaturated fatty acid (PUFA) levels vs an obesogenic diet enriched in SFAs. Adult male mice were fed for eight weeks either (1) a control $16 \%$ fat energy (en) diet with 5.7\% en OA and 4.4\% en SFA, (2) a 50\% fat en diet with $33 \%$ en OA and $9.9 \%$ en SFA, or (3) a 50\% en diet with a high SFA diet with 33\% en SFA and 9.1\% en OA. Dietary levels and intake of linoleic acid (LA; 18:2n-6) and $\alpha$-linolenic acid (ALA; 18:3n-3) were constant between the experimental groups. Several peripheral organs (liver, heart, kidney, and adipose) were analyzed for lipid composition and oxylipin analysis was performed for liver and adipose. Our data demonstrate that a high OA diet reduced tissue content of LA and ALA $(\geq 30 \%)$ in phospholipid and neutral lipid fractions, reduced the content of some LA-derived and ALA-derived oxylipins in liver and adipose, and conversely, elevated hepatic content of $\mathrm{PGF}_{2 \alpha}$. In all tissues examined, except for adipose, levels of arachidonic acid (ARA; 20:4n-6) and docosahexaenoic acid (DHA; 22:6n-3) were either elevated or unaffected by the obesogenic diets. Our data indicate that the non-essential fatty content of obesogenic diets impacts PUFA content in peripheral tissues and influences the levels of bioactive oxylipins.
\end{abstract}

\section{Introduction}

Obesity is a world-wide medical issue that affects over $30 \%$ of populations in many developed and developing countries [1,2]. There is a growing appreciation that dietary fatty acid composition impacts the development of obesity and its ensuing comorbidities such as insulin resistance, inflammation, and hepatic steatosis [3-5]. Saturated fatty acids (SFA) and monounsaturated fatty acids (MUFA) are often viewed as diametrically opposed with respect to negative and positive health outcomes. The 2015-2020 US Dietary Guidelines for Americans recommend that the diets contain no more than $10 \%$ of energy as SFAs [6]. Prospective clinical studies, including the PrediMed study, suggest that diets rich in olive oil containing the MUFA oleic acid (OA; 18:1n-
9) reduce cardiovascular disease risk [7]. Studies in rodents suggest that the dietary content of the polyunsaturated fatty acid (PUFA) linoleic acid (LA; 18:2n-6) modulates obesity development, while one clinical trial indicates a decrease in steatotic indices in people eating $n$ 6 PUFA-rich vs SFA-rich diets [8-10].

Long chain (LC) PUFA, including n-6 and n-3 LCPUFA, have important physiological functions in the body and impact several systems [11]. Some data suggest that obesogenic comorbidities including cardiovascular disease are the result of defects in PUFA metabolism, either from reducing the elongation and desaturation of $n-3$ LCPUFA, or from altering the levels of oxylipins that encompass a number of enzymatically and non-enzymatically derived species [1216]. However, there are scant data comparing these endpoints in which

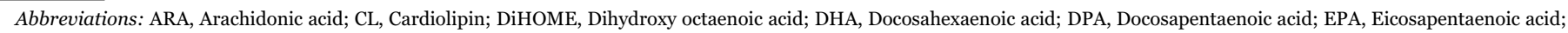

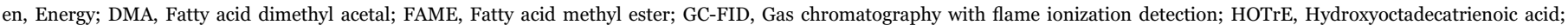

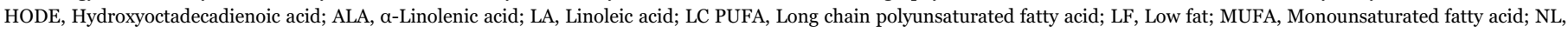

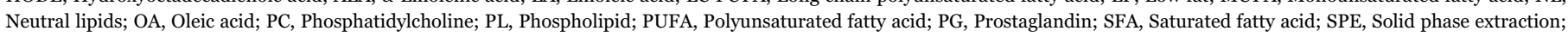
TAG, Triacylglycerol; triHOME, Trihydroxyoctaenoic acid

Support: This was supported through USDA-ARS Project 3062-51000-053-00D (MJP) and NSERC Discovery Grant 03733 (HMA).

* Corresponding author at: USDA-ARS Grand Forks Human Nutrition Research Center, 2420 2nd Avenue North, Grand Forks, ND 58203-9034, USA. 
the diets were well-controlled for n-3 and n-6 PUFA content. This is problematic given that $\alpha$-linolenic acid (ALA; 18:3n-3) and LA compete for the same enzymatic pathways leading to synthesis of n-3 LCPUFA like docosahexaenoic acid (DHA; 22:6n-3) and the n-6 LCPUFA arachidonic acid (ARA; 20:4n-6), respectively [17].

Less data are known regarding the effect of OA and SFA (both considered non-essential fatty acids) upon PUFA metabolism, particularly in under the influence of high-fat, hypercaloric diets. ALA and LA are considered essential fatty acids as they cannot be synthesized de novo and must be obtained from the diet. Without consumption of preformed n-3 LCPUFA like DHA or eicosapentaenoic acid (EPA; 20:5n-3), these n-3 PUFA must be formed from dietary ALA $[18,19]$. Previous data indicate that OA can reduce the content of LA in tissues when LA content is low in the diet $[20,21]$. Other data demonstrate that reductions in LA in the diet modify mitochondrial function as LA is a major component of cardiolipin [22,23]. The extent to which an obesogenic diet made with OA vs SFA modifies oxylipins mediators is not known.

In this work, we tested the hypothesis that obesogenic diets enriched in OA reduce PUFA levels vs an obesogenic diet enriched in SFA in mice. The fatty acid levels of phospholipid (PL) and neutral lipid (NL) pools were studied in several peripheral organs (liver, heart, kidney, and adipose) in order to gain insight into whether the PUFA content of these different metabolic pools were selectively modified by $\mathrm{OA}$ and SFA intake. The availability of hepatic and adipose tissue allowed for testing the hypothesis that OA vs SFA intake modifies the levels of oxylipins in these tissues. Our data demonstrate that a high OA diet reduced tissue content of LA and ALA, reduced the content of some LA-derived and ALA-derived oxylipins in liver and adipose. In all tissues examined, except for adipose, levels of the LCPUFA ARA and DHA were either elevated or not affected by the obesogenic diets.

\section{Methods}

\subsection{Animal experimentation}

All experiments were approved by the Institutional Animal Care and Use Committee of the USDA/Agricultural Research Service, Grand Forks Human Nutrition Research Center. Male, C57BL/6 mice (12 week old) were purchased from Harlan Laboratories (Indianapolis, IN). The study was powered such that $n=8$ per group $(\alpha=0.05)$ provided over $95 \%$ power to detect a $2.7 \mu \mathrm{mol} / \mathrm{g}$ tissue difference in hepatic ALA content between the three diet groups with a standard deviation of $1.3 \mu \mathrm{mol} / \mathrm{gram}$ tissue. The estimates used for the power analysis were based on our previous publication [24]. Following acclimation for one week, mice were equally distributed by weight into three diet groups and remained in these groups for 8 weeks. Mice were housed individually in stainless steel wire cages. Diets were based on the AIN93G formulation [25]. Diet formulation and fatty acid compositions of the diets are provided in Tables 1 and 2, respectively. Mice were fed either (1) a low-fat (LF), control diet $(4.3 \mathrm{kcal} / \mathrm{g})$ consisting of $16 \%$ energy (en) as fat, (2) an obesogenic (50\% en fat; $5.5 \mathrm{kcal} / \mathrm{g}$ ), high OA (33\% en) content diet, or (3) an obesogenic (50\% en fat diet; $5.4 \mathrm{kcal} / \mathrm{g}$ ) with high SFA (33\% en) content diet. All diets had nearly identical content of ALA and LA. Diet components were sourced as previously described [24]. Fresh diet was provided daily. Food consumption was measured on two separate days biweekly and presented as a mean for that week. Body mass was measured weekly. Body composition was determined by use of an EchoMRI Whole Body Composition Analyzer (Echo Medical Systems, Houston, TX) at the beginning and end of the study.

After 8 weeks, mice were fasted for six hours prior to sacrifice starting at approximately 3 a.m. A six hour fast is recommended for determination of glycemic endpoints in mice [26]. Blood glucose was determined using TRUEresult blood glucose meter and TRUEtest blood glucose test strips (NIPRO Diagnostics, Fort Lauderdale, FL)
Table 1

Dietary formulations.

\begin{tabular}{llll}
\hline & $\begin{array}{l}16 \% \text { Fat } \\
\text { Energy } \\
\text { LF }\end{array}$ & $\begin{array}{l}\text { 50\% Fat } \\
\text { Energy } \\
\text { High OA }\end{array}$ & High SFA \\
\cline { 2 - 4 } Diet Components & \% En and Amount $(\mathrm{g} / \mathrm{kg})$ & \\
\hline Protein & $20 \%$ En & $20 \% \mathrm{En}$ & $20 \% \mathrm{En}$ \\
Casein & 200 & 250 & 250 \\
Carbohydrate & $64 \%$ En & $30 \% \mathrm{En}$ & $30 \% \mathrm{En}$ \\
Cornstarch & 540 & 250 & 250 \\
Sucrose & 100 & 125 & 125 \\
Fat & $16 \%$ En & $50 \% \mathrm{En}$ & $50 \% \mathrm{En}$ \\
High oleic sunflower oil & 17 & 211 & 20 \\
Flaxseed oil & 18 & 24 & 22 \\
corn oil & 20 & 0.0 & 17 \\
Coconut oil & 8 & 21 & 110 \\
Butter Fat & 8 & 22 & 110 \\
Cystine & 3.0 & 3.6 & 3.6 \\
Teklad AIN93 Vitamin & 10 & 12 & 12 \\
$\quad$ Mix & & & \\
Teklad AIN93 Mineral & 35 & 42 & 42 \\
$\quad$ Mix & & 3 & 3 \\
Choline Bitartrate & 2.5 & 62 & 62 \\
Cellulose & 41 & $5.5 \pm 0.1$ & $5.4 \pm 0.1$ \\
kcal/ga & $4.3 \pm 0.1$ & & \\
\hline
\end{tabular}

LF, Low fat; OA, Oleic acid; SFA, Saturated fatty acid.

${ }^{\text {a }}$ Data are mean $\pm \mathrm{SD} ; n=3$.

Table 2

Percent energy provided by fatty acids in the experimental diets.

\begin{tabular}{llll}
\hline $\begin{array}{l}\text { Major } \\
\text { Fatty acids }\end{array}$ & $\begin{array}{l}\mathbf{1 6 \%} \text { Fat Energy } \\
\text { LF }\end{array}$ & $\begin{array}{l}\mathbf{5 0 \%} \text { Fat Energy } \\
\text { High OA }\end{array}$ & $\begin{array}{l}\mathbf{5 0 \%} \text { Fat Energy } \\
\text { High SFA }\end{array}$ \\
\hline 10:0 & 0.2 & 0.1 & 0.3 \\
$12: 0$ & 0.7 & 1.4 & 7.1 \\
$14: 0$ & 0.7 & 1.9 & 7.8 \\
$16: 0$ & 1.9 & 4.0 & 11.6 \\
$18: 0$ & 0.9 & 2.5 & 6.5 \\
Total SFA & 4.4 & 9.9 & 33.3 \\
18:1n-9 & 5.7 & 33.0 & 9.1 \\
18:2n-6 & 3.5 & 3.4 & 3.4 \\
18:3n-3 & 2.1 & 2.1 & 2.1 \\
\hline
\end{tabular}

Data are the mean of three independent samples. Standard deviations are less $\leq 5 \%$ of the mean value. LF, Low fat; OA, Oleic acid; SFA, Saturated fatty acid.

on blood derived from the tail clip of conscious mice. Mice were then anesthetized and exsanguinated as described previously [24]. Tissues (liver, heart, kidney, and epididymal adipose) were removed, frozen in liquid nitrogen, and stored at $-80^{\circ} \mathrm{C}$.

\subsection{Lipid analyses}

Tissues were pulverized under liquid $\mathrm{N}_{2}$-cooled conditions [24]. Lipids were extracted and separated by solid phase extraction (SPE) into PL and NL (triacylglycerol, diacylglycerol, cholesterol, cholesteryl esters and unesterified fatty acid) pools as described previously [24].

Tripentadecanoin (Nu-Chek Prep. Inc., Elysian, MN) and 1,2diheptadecanoyl-sn-glycero-3-phosphocholine (Avanti Polar Lipids, Inc., Alabaster, $\mathrm{AL}$ ) were added to each sample as internal standards prior to the SPE step for recovery of NL and PL, respectively. Fatty acids were quantified using fatty acid methyl ester (FAME) derivatization with acetyl chloride followed by gas chromatography with flame ionization detection (GC-FID). Fatty acid dimethyl acetal (DMA) resulting from the hydrolysis of plasmenyl fatty acids in acetyl chloride reaction were quantified by GC-FID using standards purchased from Avanti Polar Lipids, Inc. (Alabaster, AL).

Kidney tissue was freeze dried prior to lipid extraction in order to remove confounds associated with potential changes in renal water 
content. Approximately $75 \mathrm{mg}$ of frozen pulverized tissue powder was weighed out into a $13 \times 100 \mathrm{~mm}$ glass test tube. Samples were freeze dried $42 \mathrm{~h} .30 \mathrm{~min}$ in a FreeZone 4.5 Plus freeze drier (Labconco, Kansas City, MO). The resulting powder was extracted as described previously [24].

\subsubsection{Separation of hepatic PLs}

The lipid extracts were dried under a stream of $\mathrm{N}_{2}$ and then dissolved in chloroform. PL and NL fractions were then separated using silicic acid column chromatography (Clarkson Chemical Company, Inc., Williamsport, PA, USA) [27]. The NL fraction was eluted with chloroform: methanol (58:1 by vol) and the PL fraction eluted with methanol. Following fractionation, NL and PL fractions were separated into individual lipid classes using thin-layer chromatography on heat-activated $\left(110^{\circ} \mathrm{C}\right)$ Whatman silica gel-60 plates. PLs were separated using chloroform: methanol:acetic acid: water (50:37.5:3:2 by vol) [28]. Bands containing individual lipid classes were identified using commercially available standards (Avanti, Polar Lipids Alabaster, AL; NuChek Prep., Elysian, MN, USA) after visualization using iodine vapor. Individual bands corresponding to commercially prepared standards were scraped into acid-washed tubes, and the phosphorus content was quantified colorimetrically on a spectrophotometer monitoring absorbance at $797 \mathrm{~nm}$ [29]. For determination of cardiolipin fatty acid content, bands co-eluting with cardiolipin standards were scraped into glass vials and subjected to FAME derivatization with acetyl chloride.

Hepatic cholesterol and hepatic TAG levels were measured as previously described using the COBAS Integra Analyzer (HoffmanLaRoche) with the respective kits [30].

\subsubsection{Oxylipin analysis}

Hepatic and adipose oxylipin levels were determined using previously published methods [31]. Livers were homogenized in ice-cold Tyrode's salt solution ( $\mathrm{pH} 7.6)$ in a 1:28 wt/volume ratio, after which Triton X-100 was added to achieve a final concentration of $0.01 \%$. Adipose tissue was ground in liquid nitrogen and dissolved in 60 volumes of $\mathrm{MeOH}$ : formic acid (100:1, by vol). An antioxidant mix $(6 \mu \mathrm{L} ; 0.2 \mathrm{~g} / \mathrm{L}$ BHT, $0.2 \mathrm{~g} / \mathrm{L}$ EDTA, $2 \mathrm{~g} / \mathrm{L}$ triphenylphosphine, and $2 \mathrm{~g} /$ L indomethacin in MeOH: EtOH:H2O (2:1:1, by vol)) and 10-20 ng of deuterated internal standards (Cayman Chemical, MI, USA) were added to aliquots of liver $(200 \mu \mathrm{L})$ and adipose $(1000 \mu \mathrm{L})$. Samples were adjusted to $\mathrm{pH}<3$ and solid phase extraction was performed using Strata-X SPE columns (Phenomenex, CA, USA) preconditioned with methanol and water ( $\mathrm{pH} 3)$. Samples were loaded onto the columns, rinsed with $10 \%$ methanol, water $(\mathrm{pH} 3$ ) and hexane before being eluted with methanol. Evaporated samples were then resuspended in solvent for analysis by HPLC-MS/MS (API 4000, AB Sciex, Canada) as described earlier [31], based on methods developed by Deems et al. [32]. Detection and quantification limits were set at 3 and 5 levels above background, respectively [31,32]. Quantification of oxylipins was determined using a stable isotope dilution method and amounts expressed as nmol/g of tissue [33].

\subsection{Statistical analyses}

Comparison of values between groups was performed by one way ANOVA with Tukey contrasts using GraphPad Prism version 5.00 for Windows (GraphPad Software, San Diego California USA, www. graphpad.com) or using SAS (version 9.3; SAS Institute Inc, Cary, NC). Two way ANOVAs were performed using GraphPad Prism software.
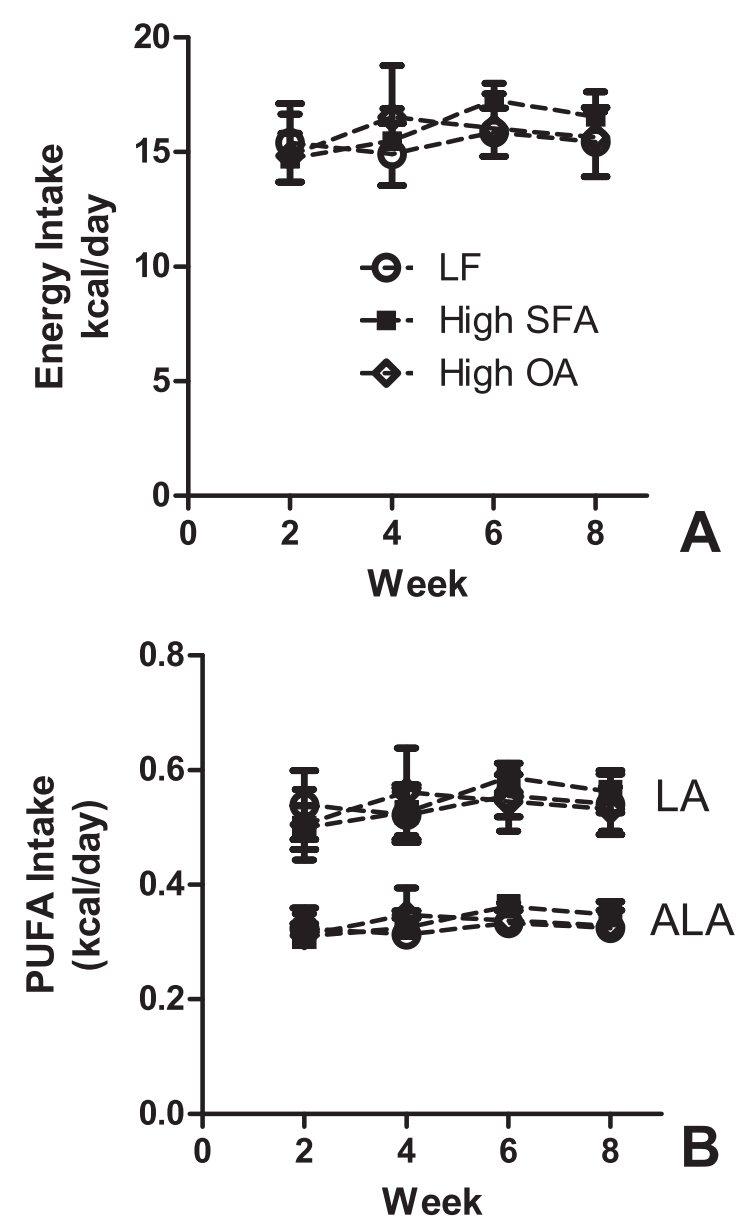

Fig. 1. Energy intake and PUFA consumption of mice on obesogenic diets. Comparison of energy intake and PUFA consumption between groups was performed using a two-way ANOVA. There were no differences $(p>0.05)$ in intake between the dietary treatments. Data are the mean $\pm \mathrm{SD} ; n=9$ control; $n=8$ for high OA and high SFA diets. LF, Low fat; OA, Oleic acid; SFA, Saturated fatty acid.

\section{Results}

\subsection{Diet intake}

Energy intake data are shown in Fig. 1. There was no difference in the caloric intake between the groups (Fig. 1A). As the diets contained nearly identical \% en of ALA and LA, the amount of LA and ALA intake was not different between the three diet groups (Fig. 1B).

\subsubsection{Morphometrics}

Following 8 weeks on the diets, all mice increased in mass with a higher mass observed in the obesogenic OA and SFA groups (Table 3). While overall fat mass and \% adiposity were elevated in the mice fed the obesogenic diets, lean body mass remained the same. The high OA diet significantly elevated hepatic mass (17\%) whereas the high SFA increased kidney mass (17\%). Both high fat diets increased the amount of epididymal adipose mass.

\subsection{Lipid composition}

\subsubsection{Liver}

Hepatic levels of TAG and cholesterol were elevated by the high OA diet but not by the high SFA diet. On the other hand, both the high OA and the high SFA diets increased fasting blood glucose levels compared to the LF controls (Fig. 2).

There was no change in the total amount of PL-esterified fatty acids in the liver. Intake of the high OA diet reduced the content of PL 
Table 3

Morphometric data. ${ }^{\mathrm{c}}$

\begin{tabular}{|c|c|c|c|}
\hline Endpoint & $\begin{array}{l}16 \% \text { Fat Energy } \\
\text { LF }\end{array}$ & $\begin{array}{l}50 \% \text { Fat Energy } \\
\text { High OA }\end{array}$ & $\begin{array}{l}50 \% \text { Fat Energy } \\
\text { High SFA }\end{array}$ \\
\hline \multicolumn{4}{|l|}{ Total Mass (g) } \\
\hline Begin & $25.4 \pm 1.7$ & $25.2 \pm 1.2$ & $25.7 \pm 1.6$ \\
\hline End & $32.3 \pm 3.0 \mathrm{a}^{\mathrm{d}}$ & $37.3 \pm 3.2^{\mathrm{b}}$ & $35.9 \pm 2.7^{b}$ \\
\hline \multicolumn{4}{|l|}{ Lean Mass (g) } \\
\hline Begin & $19.8 \pm 1.4$ & $19.5 \pm 1.1$ & $20.4 \pm 1.6$ \\
\hline End & $20.8 \pm 1.2$ & $21.7 \pm 1.2$ & $21.7 \pm 0.8$ \\
\hline \multicolumn{4}{|l|}{ Fat Mass (g) } \\
\hline Begin & $1.8 \pm 0.6$ & $2.1 \pm 0.6$ & $1.7 \pm 0.5$ \\
\hline End & $8.3 \pm 2.1^{\mathrm{a}}$ & $12.5 \pm 2.4^{\mathrm{b}}$ & $10.9 \pm 2.9^{\mathrm{a}, \mathrm{b}}$ \\
\hline \multicolumn{4}{|l|}{ \% Body Fat } \\
\hline Begin & $7.2 \pm 2.5$ & $8.2 \pm 2.2$ & $5.1 \pm 1.5$ \\
\hline End & $25.5 \pm 4.6^{\mathrm{a}}$ & $33.2 \pm 2.5^{\mathrm{b}}$ & $30.1 \pm 6.0^{\mathrm{a}, \mathrm{b}}$ \\
\hline Liver Mass (g) & $1.2 \pm 0.1^{\mathrm{a}}$ & $1.4 \pm 0.2^{\mathrm{b}}$ & $1.3 \pm 0.1^{\mathrm{a}, \mathrm{b}}$ \\
\hline Heart Mass (g) & $0.13 \pm 0.01$ & $0.13 \pm 0.01$ & $0.13 \pm 0.01$ \\
\hline Kidney Mass (g) & $0.35 \pm 0.02^{\mathrm{a}}$ & $0.36 \pm 0.02^{\mathrm{a}}$ & $0.41 \pm 0.02^{b}$ \\
\hline Epididymal (g) & $1.2 \pm 0.3^{\mathrm{a}}$ & $1.7 \pm 0.3^{\mathrm{b}}$ & $1.7 \pm 0.4^{\mathrm{b}}$ \\
\hline \multicolumn{4}{|l|}{ Adipose Mass } \\
\hline \multirow[t]{2}{*}{ Blood Glucose } & $76.4 \pm 9.3^{\mathrm{a}}$ & $93.1 \pm 6.9^{b}$ & $86.7 \pm 5.0^{\mathrm{b}}$ \\
\hline & $n=9$ & $n=8$ & $n=8$ \\
\hline
\end{tabular}

LF, Low fat; OA, Oleic acid; SFA, Saturated fatty acid.

${ }^{\mathrm{c}}$ Data are the mean \pm the S.D.

${ }^{\mathrm{d}}$ Means in rows with different superscript are significantly different $(\mathrm{p}<0.05)$ by one way ANOVA.

esterified LA by $30 \%(8.2 \pm 1.1 \mu \mathrm{mol} / \mathrm{g}$ vs $11.7 \pm 1.4 \mu \mathrm{mol} / \mathrm{g}$ for LF $)$ and the content of ALA by $57 \%(0.22 \pm 0.05 \mu \mathrm{mol} / \mathrm{g}$ vs $0.51 \pm$ $0.05 \mu \mathrm{mol} / \mathrm{g}$ for LF) (Table 4). The decrement in LA and ALA was nearly identical to the increase in OA $(4.3 \mu \mathrm{mol} / \mathrm{g})$ in this fraction in high OA-fed mice. The reduction of 18 carbon PUFA did not yield differences in longer n-6 PUFA or n-3 PUFA except for a reduction in the minor LCPUFA, n-3 docosapentaenoic acid (DPAn-3; 22:5n-3). Intake of the high SFA diet caused a small increase in DPAn-3 content.

In agreement with the hepatic TAG results, the hepatic content of NL fatty acids was doubled in the animals receiving the high OA diet $(445 \pm 160 \mu \mathrm{mol} / \mathrm{g})$ vs LF controls $(218 \pm 46 \mu \mathrm{mol} / \mathrm{g})$ primarily the result of the large increase in OA in this fraction (Table 5). Similar to our previous results, consumption of the high OA diet resulted in an increase in DHA and ARA and other fatty acids 20 carbons and longer while reducing ALA content in the NL fraction.

The content of hepatic phosphatidylcholine was elevated $6.5 \%$ in animals consuming the high OA diet compared to the control diet. In this same dietary group, phosphatidylethanolamine was reduced $10.6 \%$ compared to controls. The content of other PL classes was not altered (data not shown). There were no changes in PL distribution in animals eating the high SFA diet compared to the LF diet.

The fatty acid content of CL can be modified by the PUFA levels in the diet $[22,23,34]$. As shown in Fig. 3, the distribution of fatty acids in the CL fraction of hepatic PL was altered by the SFA and OA content of the diets consumed. The OA content was elevated by intake of the high OA diet but not that of LA. Intake of the high SFA diet elevated CL content of DHA and ARA, while surprisingly lowering the CL content of palmitate.

\subsubsection{Kidney}

Renal PL was altered by intake of the obesogenic diets (Table 6). Similar to liver, PL-esterified LA and ALA as well as n-3 and n-6 PUFA elongation and desaturation intermediates were reduced by $\mathrm{OA}$ intake and ARA and DHA were not changed. Conversely, intake of the high SFA diet slightly increased the levels of ARA and doubled the content of DPAn-6. Similarly, levels of EPA (19\%), DPAn-3 (92\%), and DHA (31\%) were elevated in mice fed the high SFA diet vs the LF diet. The
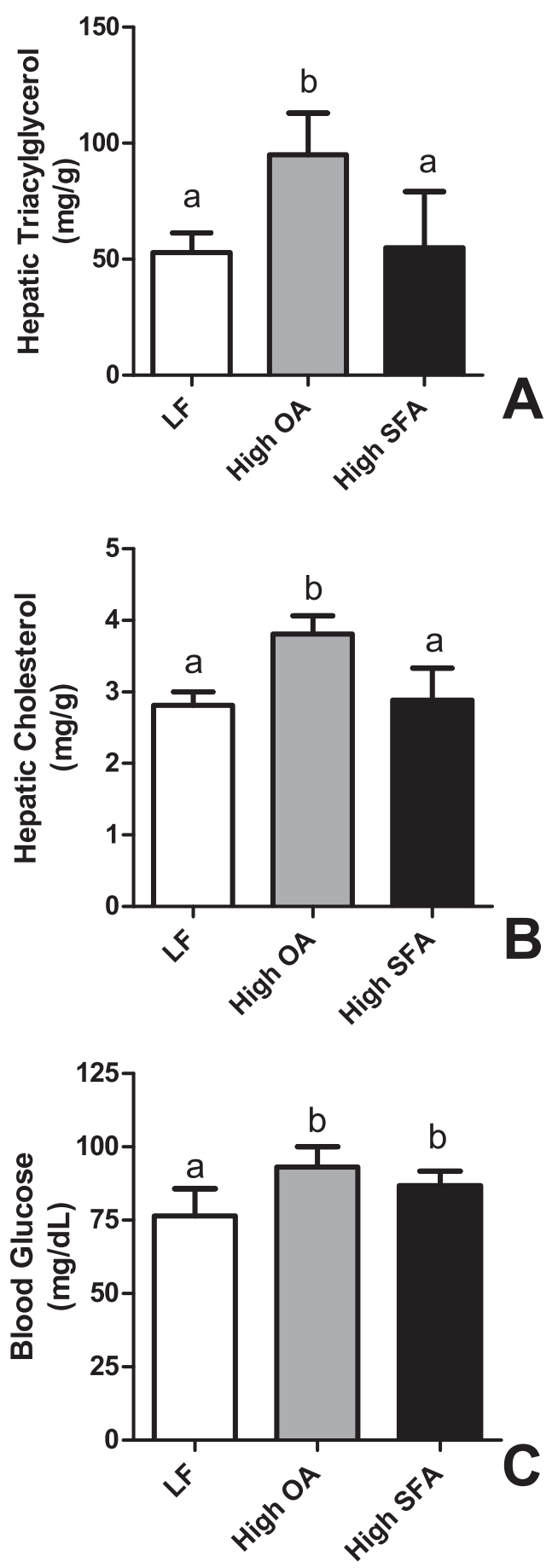

Fig. 2. The obesogenic, high SFA diet prevents hepatic lipid deposition vs an obesogenic high OA diet. Data are the mean $\pm S D ; n=9$ control; $n=8$ for high OA and high SFA diets. Data were compared using a one-way ANOVA with Tukey's contrasts. Columns with different letters are significantly different, $\mathrm{p} \leq 0.05$. LF, Low fat; OA, Oleic acid; SFA, Saturated fatty acid.

high oleic diet intake reduced NL esterified LA and ALA and reduced DHA content by $37 \%$ in the NL fraction (Table 7).

\subsubsection{Heart}

Similar to results in the liver, the high OA diet decreased the cardiac content of PL-esterified LA in a nearly stoichiometric manner and reduced the PL content of ALA (Table 8). While PL-esterified levels of ARA were not changed by OA intake, ARA was elevated $64 \%(5.6 \pm$ $0.8 \mu \mathrm{mol} / \mathrm{g})$ by the high SFA diet vs the LF animals $(3.4 \pm 1.4 \mu \mathrm{mol} / \mathrm{g})$. DHA content in the PL fraction was not altered between the diet 
Table 4

Impact of high OA vs high SFA diets on hepatic phospholipid fatty acids. ${ }^{\mathrm{d}}$

\begin{tabular}{|c|c|c|c|c|c|c|c|c|c|}
\hline \multirow{2}{*}{$\begin{array}{l}\text { Fatty } \\
\text { acid }\end{array}$} & \multicolumn{3}{|c|}{$\begin{array}{l}16 \% \text { Fat Energy } \\
\text { LF }\end{array}$} & \multicolumn{3}{|c|}{$\begin{array}{l}50 \% \text { Fat Energy } \\
\text { High OA }\end{array}$} & \multicolumn{3}{|c|}{$\begin{array}{l}50 \% \text { Fat Energy } \\
\text { High SFA }\end{array}$} \\
\hline & 0.00 & \pm & 0.00 & 0.00 & \pm & 0.00 & 0.01 & \pm & 0.03 \\
\hline 14:0 & 0.10 & \pm & $0.10^{\mathrm{ae}}$ & 0.11 & \pm & $0.10^{\mathrm{a}, \mathrm{b}}$ & 0.26 & \pm & $0.17^{\mathrm{b}}$ \\
\hline $16: 0$ & 19.5 & \pm & $2.0^{\mathrm{a}}$ & 16.7 & \pm & $2.1^{\mathrm{b}}$ & 17.9 & \pm & $1.6^{\mathrm{a}, \mathrm{b}}$ \\
\hline 18:0 & 11.8 & \pm & $1.3^{\mathrm{a}}$ & 12.7 & \pm & $1.5^{\mathrm{a}, \mathrm{b}}$ & 13.3 & \pm & $1.0^{\mathrm{a}}$ \\
\hline 20:0 & 0.20 & \pm & $0.02^{\mathrm{a}}$ & 0.19 & \pm & $0.03^{\mathrm{a}}$ & 0.23 & \pm & $0.02^{\mathrm{c}}$ \\
\hline 22:0 & 0.04 & \pm & 0.02 & 0.05 & \pm & 0.01 & 0.05 & \pm & 0.01 \\
\hline $16: 1 n-7$ & 1.5 & \pm & $0.2^{\mathrm{a}}$ & 0.4 & \pm & $0.1^{\mathrm{b}}$ & 1.1 & \pm & $0.2^{\mathrm{c}}$ \\
\hline $18: 1 n-7$ & 1.2 & \pm & $0.2^{\mathrm{a}}$ & 0.7 & \pm & $0.2^{\mathrm{b}}$ & 0.7 & \pm & $0.2^{\mathrm{b}}$ \\
\hline $18: 1 n-9$ & 7.3 & \pm & $0.9^{\mathrm{a}}$ & 11.6 & \pm & $1.2^{\mathrm{b}}$ & 6.4 & \pm & $0.8^{\mathrm{a}}$ \\
\hline $20: 1 n-9$ & 0.16 & \pm & $0.02^{\mathrm{a}}$ & 0.31 & \pm & $0.05^{\mathrm{b}}$ & 0.11 & \pm & $0.02^{\mathrm{c}}$ \\
\hline $22: 1 n-9$ & 0.00 & \pm & 0.00 & 0.00 & \pm & 0.00 & 0.00 & \pm & 0.00 \\
\hline $18: 2 n-6$ & 11.7 & \pm & $1.4^{\mathrm{a}}$ & 8.2 & \pm & $1.1^{\mathrm{b}}$ & 11.1 & \pm & $1.4^{\mathrm{a}}$ \\
\hline $18: 3 n-6$ & 0.17 & \pm & $0.02^{\mathrm{a}}$ & 0.12 & \pm & $0.02^{\mathrm{b}}$ & 0.16 & \pm & $0.03^{\mathrm{a}}$ \\
\hline $20: 2 n-6$ & 0.11 & \pm & $0.02^{\mathrm{a}}$ & 0.09 & \pm & $0.01^{\mathrm{b}}$ & 0.09 & \pm & $0.01^{\mathrm{b}}$ \\
\hline $20: 3 n-6$ & 1.2 & \pm & $0.2^{\mathrm{a}}$ & 1.7 & \pm & $0.4^{\mathrm{b}}$ & 1.0 & \pm & $0.2^{\mathrm{a}}$ \\
\hline $20: 4 n-6$ & 9.6 & \pm & 1.3 & 10.4 & \pm & 1.8 & 9.9 & \pm & 1.1 \\
\hline $22: 4 n-6$ & 0.08 & \pm & 0.01 & 0.07 & \pm & 0.01 & 0.08 & \pm & 0.01 \\
\hline $18: 3 n-3$ & 0.51 & \pm & $0.05^{\mathrm{a}}$ & 0.22 & \pm & $0.05^{\mathrm{b}}$ & 0.49 & \pm & $0.07^{\mathrm{a}}$ \\
\hline $20: 3 n-3$ & 0.07 & \pm & $0.01^{\mathrm{a}}$ & 0.05 & \pm & $0.02^{\mathrm{b}}$ & 0.08 & \pm & $0.01^{\mathrm{a}}$ \\
\hline $20: 5 n-3$ & 2.4 & \pm & 0.4 & 2.4 & \pm & 0.4 & 2.2 & \pm & 0.4 \\
\hline $22: 5 n-3$ & 0.81 & \pm & $0.07^{\mathrm{a}}$ & 0.45 & \pm & $0.04^{\mathrm{b}}$ & 0.94 & \pm & $0.07^{\mathrm{c}}$ \\
\hline $22: 6 n-3$ & 10.1 & \pm & 1.2 & 10.0 & \pm & 1.2 & 10.3 & \pm & 0.9 \\
\hline \multirow[t]{2}{*}{ Total } & 78.5 & \pm & 8.5 & 76.6 & \pm & 9.3 & 76.4 & \pm & 6.7 \\
\hline & $n=9$ & & & $n=8$ & & & $n=8$ & & \\
\hline
\end{tabular}

LF, Low fat; OA, Oleic acid; SFA, Saturated fatty acid.

${ }^{\mathrm{d}}$ Data are mean \pm SD and are $\mu \mathrm{mol} / \mathrm{g}$ wet weight .

${ }^{\mathrm{e}}$ Means with different letters are significantly different $(\mathrm{p}<0.05)$ from values in the same row by one way ANOVA.

groups; however cardiac levels of DPAn-3 were lowered by intake of the high OA diet (38\%) and elevated by the high SFA diet (44\%). NL content of ALA and LA were also reduced by high OA intake $60 \%$ and $52 \%$, respectively (Table 9). While minor alterations in $n-3$ and $n-6$ LCPUFA were observed, neither high fat diet modified ARA or DHA in the NL fraction.

\subsubsection{Adipose tissue}

The content of SFA and OA was elevated in the animals eating the high-SFA and high-OA diets respectively. Levels of 10:0, 12:0 and 14:0

Table 5

Impact of high OA vs high SFA diets on hepatic neutral lipid fatty acids. ${ }^{\mathrm{d}}$

\begin{tabular}{|c|c|c|c|c|c|c|c|c|c|}
\hline \multirow{2}{*}{$\begin{array}{l}\text { Fatty } \\
\text { acid }\end{array}$} & \multicolumn{3}{|c|}{$\begin{array}{l}\text { 16\% Fat Energy } \\
\text { LF }\end{array}$} & \multicolumn{3}{|c|}{$\begin{array}{l}50 \% \text { Fat Energy } \\
\text { High OA }\end{array}$} & \multicolumn{3}{|c|}{$\begin{array}{l}50 \% \text { Fat Energy } \\
\text { High SFA }\end{array}$} \\
\hline & 0.2 & \pm & $0.1^{\mathrm{ae}}$ & 0.4 & \pm & $0.1^{\mathrm{b}}$ & 2.0 & \pm & $0.5^{\mathrm{c}}$ \\
\hline $14: 0$ & 1.6 & \pm & $1.3^{\mathrm{a}}$ & 2.0 & \pm & $1.8^{\mathrm{a}}$ & 7.0 & \pm & $2.6^{\mathrm{b}}$ \\
\hline $16: 0$ & 59.1 & \pm & 12.1 & 90.8 & \pm & 38.0 & 57.3 & \pm & 27.1 \\
\hline 18:0 & 2.8 & \pm & $0.5^{\mathrm{a}}$ & 4.9 & \pm & $1.2^{\mathrm{b}}$ & 4.2 & \pm & $1.1^{\mathrm{b}}$ \\
\hline $20: 0$ & 0.5 & \pm & $0.1^{\mathrm{a}}$ & 0.9 & \pm & $0.2^{\mathrm{b}}$ & 0.9 & \pm & $0.3^{\mathrm{b}}$ \\
\hline $22: 0$ & 0.07 & \pm & $0.03^{\mathrm{a}}$ & 0.13 & \pm & $0.02^{\mathrm{b}}$ & 0.14 & \pm & $0.03^{\mathrm{b}}$ \\
\hline $16: 1 n-7$ & 15.6 & \pm & $4.0^{\mathrm{a}}$ & 7.4 & \pm & $4.4^{\mathrm{b}}$ & 10.8 & \pm & $5.8^{\mathrm{a}, \mathrm{b}}$ \\
\hline $18: 1 n-7$ & 4.4 & \pm & $1.3^{\mathrm{a}}$ & 3.9 & \pm & $2.6^{\mathrm{a}, \mathrm{b}}$ & 2.1 & \pm & $1.5^{\mathrm{b}}$ \\
\hline $18: 1 n-9$ & 85.8 & \pm & $18.3^{\mathrm{a}}$ & 282.3 & \pm & $100.3^{\mathrm{b}}$ & 71.5 & \pm & $37.8^{\mathrm{a}}$ \\
\hline $20: 1 n-9$ & 1.4 & \pm & $0.3^{\mathrm{a}}$ & 5.5 & \pm & $1.9^{\mathrm{b}}$ & 1.0 & \pm & $0.5^{\mathrm{a}}$ \\
\hline $22: 1 n-9$ & 0.19 & \pm & $0.05^{\mathrm{a}}$ & 0.55 & \pm & $0.09^{\mathrm{b}}$ & 0.18 & \pm & $0.08^{\mathrm{a}}$ \\
\hline $18: 2 n-6$ & 27.4 & \pm & 6.8 & 22.5 & \pm & 6.6 & 24.0 & \pm & 9.1 \\
\hline $18: 3 n-6$ & 0.7 & \pm & 0.2 & 0.7 & \pm & 0.1 & 0.9 & \pm & 0.3 \\
\hline $20: 2 n-6$ & 0.2 & \pm & 0.1 & 0.2 & \pm & 0.1 & 0.2 & \pm & 0.1 \\
\hline $20: 3 n-6$ & 0.5 & \pm & $0.1^{\mathrm{a}}$ & 0.9 & \pm & $0.3^{\mathrm{b}}$ & 0.5 & \pm & $0.2^{\mathrm{a}}$ \\
\hline $20: 4 n-6$ & 0.9 & \pm & $0.2^{\mathrm{a}}$ & 1.3 & \pm & $0.3^{\mathrm{b}}$ & 1.2 & \pm & $0.4^{\mathrm{a}, \mathrm{b}}$ \\
\hline $22: 4 n-6$ & 0.2 & \pm & 0.0 & 0.2 & \pm & 0.1 & 0.2 & \pm & 0.1 \\
\hline $18: 3-3$ & 9.4 & \pm & $2.8^{\mathrm{a}}$ & 6.3 & \pm & $1.5^{\mathrm{b}}$ & 9.4 & \pm & $3.8^{\mathrm{a}, \mathrm{b}}$ \\
\hline $20: 3 n-3$ & 0.2 & \pm & 0.1 & 0.2 & \pm & 0.1 & 0.2 & \pm & 0.1 \\
\hline $20: 5 n-3$ & 2.2 & \pm & 0.5 & 2.5 & \pm & 0.6 & 2.8 & \pm & 1.4 \\
\hline $22: 5 n-3$ & 1.7 & \pm & $0.4^{\mathrm{a}}$ & 2.5 & \pm & $0.7^{\mathrm{b}}$ & 2.7 & \pm & $1.3^{\mathrm{a}, \mathrm{b}}$ \\
\hline $22: 6 n-3$ & 3.6 & \pm & $0.8^{\mathrm{a}}$ & 9.2 & $\begin{array}{l} \pm \\
\pm\end{array}$ & $2.4^{\mathrm{b}}$ & 5.4 & $\begin{array}{l} \pm \\
\pm\end{array}$ & $1.8^{\mathrm{c}}$ \\
\hline \multirow[t]{2}{*}{ Total } & 218.7 & \pm & $46.8^{\mathrm{a}}$ & 445.6 & \pm & $160.3^{\mathrm{b}}$ & 204.5 & \pm & $94.9^{\mathrm{a}}$ \\
\hline & $n=9$ & & & $n=8$ & & & $n=8$ & & \\
\hline
\end{tabular}

LF, Low fat; OA, Oleic acid; SFA, Saturated fatty acid.

${ }^{\mathrm{d}}$ Data are mean $\pm \mathrm{SD}$ and are $\mu \mathrm{mol} / \mathrm{g}$ wet weight.

${ }^{e}$ Means with different letters are significantly different $(\mathrm{p}<0.05)$ from values in the same row by one way ANOVA. 

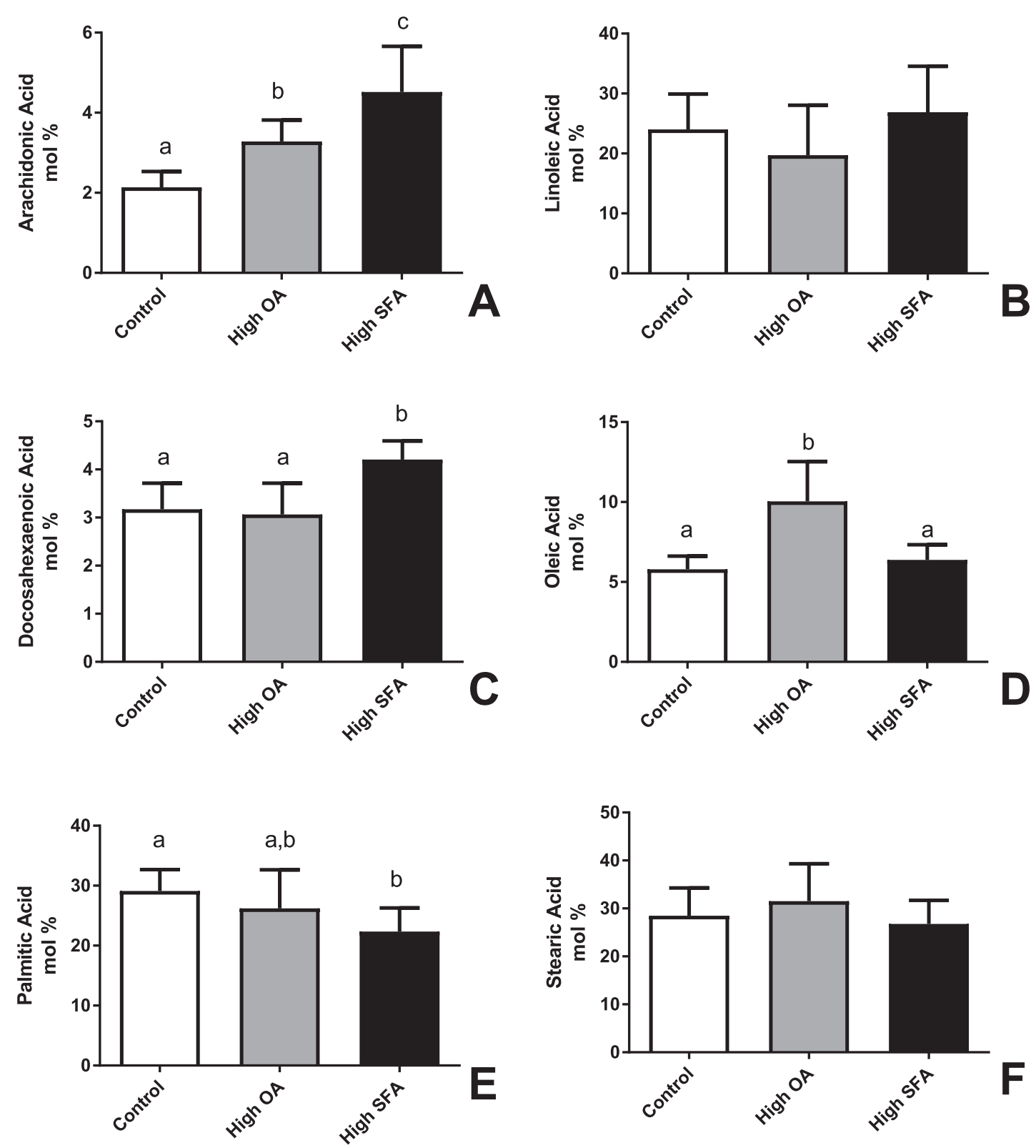

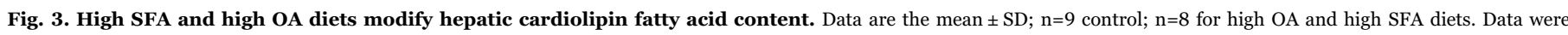
compared using a one-way ANOVA with Tukey's contrasts. Columns with different letters are significantly different, p $\leq 0.05$. LF, Low fat; OA, Oleic acid; SFA, Saturated fatty acid.

were elevated over 4-6-fold. 16:0 and 18:0 were also elevated by SFA intake. High OA intake led to a decrease in SFA content (14:0, 16:0, and 18:0) in epididymal adipose, while nearly doubling the content of OA (Table 10).

PUFA contents (n-6 PUFA and n-3) per gram adipose tissue were reduced in animals eating the high-fat diets; however, greater decreases were observed with intake of the high OA diet (Table 10). LA was reduced $58 \%$ and $37 \%$ in animals eating the high OA and the high SFA diet vs controls, respectively. ARA content was reduced $39 \%$ vs controls by high OA intake. ALA content was similarly reduced as LA. N-3 LCPUFA including EPA, DPAn-3 and DHA were lower in both high-fat groups although lower levels of EPA and DPAn-3 were observed in adipose derived from high OA-fed vs high SFA-fed mice.

Because the visceral adipose tissue store expanded as a result of eating a high-fat, obesogenic diet, we determined if the total adipose pool of PUFA was similarly reduced by intake of the obesogenic diets. We transformed the fatty acid content per gram adipose tissue to the fatty acid in the whole depot through multiplying the data above by the mass of the corresponding visceral adipose tissues (Table 11). Following this transformation, differences in ARA and DHA were not observed; however, decreases in ALA (42\%) and LA (38\%) still persisted for those mice eating the high OA diet, but not the high SFA diet.

\subsection{Oxylipins}

Given the changes in PUFA content observed, we further examined the impact of MUFA and SFA upon PUFA metabolism through analysis of oxylipins, bioactive mediators derived through cyclooxygenase, lipoxygenase, and cytochrome P450-mediated pathways. Because of the availability of tissues, we were able to analyze oxylipin content in liver and visceral, epididymal adipose. The analytical method was designed to detect approximately 160 oxylipin species. In liver, 70 oxylipins were detected but only three were changed by the obesogenic diets (Fig. 4). The 9-hydroxy derivatives of LA and ALA, 9-hydroxyoctadecadienoic acid (9-HODE) and 9-hydroxyoctadecatrienoic acid (9-HOTrE), were reduced compared to the control diet by $39 \%$ (9HODE) and 53\% (9-HOTrE). On the other hand, intake of the high MUFA elevated prostaglandin (PG) $\mathrm{PGF}_{2 \alpha}$ by $79 \%$. A comprehensive 
Table 6

Impact of high OA vs high SFA diets on renal phospholipid lipid fatty acids.

\begin{tabular}{|c|c|c|c|c|c|c|c|c|c|c|c|}
\hline $\begin{array}{l}\text { Fatty } \\
\text { acid }\end{array}$ & $\begin{array}{l}16 \% \\
\text { LF }\end{array}$ & & & Energ & & & & & & $\begin{array}{l}\text { 50\% Fat Energy } \\
\text { High SFA }\end{array}$ & \\
\hline $12: 0$ & 0.00 & \pm & 0.00 & 0.01 & & \pm & 0.03 & 0.10 & & \pm & 0.09 \\
\hline $14: 0$ & 1.1 & \pm & $0.4^{\mathrm{ae}}$ & 1.2 & & \pm & $0.7^{\mathrm{a}}$ & 2.8 & & \pm & $1.2^{\mathrm{b}}$ \\
\hline $16: 0$ & 62.8 & \pm & $4.2^{\mathrm{a}}$ & 57.0 & & \pm & $3.4^{\mathrm{b}}$ & 59.5 & & \pm & $4.1^{\mathrm{a}, \mathrm{b}}$ \\
\hline 18:0 & 38.9 & \pm & $2.2^{\mathrm{a}, \mathrm{b}}$ & 37.4 & & \pm & $2.1^{\mathrm{a}}$ & 41.7 & & \pm & $2.6^{\mathrm{b}}$ \\
\hline 20:0 & 0.46 & \pm & $0.03^{\mathrm{a}}$ & 0.39 & & \pm & $0.03^{\mathrm{b}}$ & 0.48 & & \pm & $0.03^{\mathrm{a}}$ \\
\hline 22:0 & 0.69 & \pm & $0.05^{\mathrm{a}}$ & 0.91 & & \pm & $0.08^{\mathrm{b}}$ & 0.83 & & \pm & $0.07^{\mathrm{b}}$ \\
\hline $16: 1 n-7$ & 1.8 & \pm & $0.3^{\mathrm{a}}$ & 0.5 & & \pm & $0.1^{\mathrm{b}}$ & 1.6 & & \pm & $0.3^{\mathrm{a}}$ \\
\hline $18: 1 n-7$ & 4.2 & \pm & $0.4^{\mathrm{a}}$ & 2.7 & & \pm & $0.2^{\mathrm{b}}$ & 3.0 & & \pm & $0.2^{\mathrm{c}}$ \\
\hline $18: 1 n-9$ & 21.3 & \pm & $1.1^{\mathrm{a}}$ & 32.8 & & \pm & $2.5^{\mathrm{b}}$ & 19.6 & & \pm & $1.1^{\mathrm{c}}$ \\
\hline $20: 1 n-9$ & 0.65 & \pm & $0.04^{\mathrm{a}}$ & 0.90 & & \pm & $0.06^{\mathrm{b}}$ & 0.54 & & \pm & $0.05^{\mathrm{c}}$ \\
\hline $22: 1 n-9$ & 0.14 & \pm & $0.07^{\mathrm{a}}$ & 0.15 & & \pm & $0.07^{\mathrm{a}}$ & 0.06 & & \pm & $0.06^{\mathrm{b}}$ \\
\hline $24: 1 n-9$ & 0.47 & \pm & $0.03^{\mathrm{a}}$ & 0.53 & & \pm & $0.04^{\mathrm{b}}$ & 0.34 & & \pm & $0.02^{\mathrm{c}}$ \\
\hline $18: 2 n-6$ & 18.0 & \pm & $0.8^{\mathrm{a}}$ & 10.9 & & \pm & $0.7^{\mathrm{b}}$ & 17.8 & & \pm & $1.5^{\mathrm{a}}$ \\
\hline $18: 3 n-6$ & 0.16 & \pm & $0.01^{\mathrm{a}}$ & 0.08 & & \pm & $0.05^{\mathrm{b}}$ & 0.19 & & \pm & $0.02^{\mathrm{c}}$ \\
\hline $20: 2 n-6$ & 0.43 & \pm & $0.02^{\mathrm{a}}$ & 0.27 & & \pm & $0.02^{\mathrm{b}}$ & 0.36 & & \pm & $0.03^{\mathrm{c}}$ \\
\hline $20: 3 n-6$ & 2.1 & \pm & $0.1^{\mathrm{a}, \mathrm{b}}$ & 2.0 & & \pm & $0.2^{\mathrm{a}}$ & 2.3 & & \pm & $0.3^{\mathrm{b}}$ \\
\hline $20: 4 n-6$ & 38.0 & \pm & $2.4^{\mathrm{a}}$ & 36.7 & & \pm & $2.3^{\mathrm{a}}$ & 40.2 & & \pm & $2.2^{\mathrm{b}}$ \\
\hline $22: 4 n-6$ & 0.40 & \pm & $0.03^{\mathrm{a}}$ & 0.33 & & \pm & $0.03^{\mathrm{b}}$ & 0.48 & & \pm & $0.03^{\mathrm{c}}$ \\
\hline $22: 5 n-6$ & 0.16 & \pm & $0.07^{\mathrm{a}}$ & 0.07 & & \pm & $0.08^{\mathrm{b}}$ & 0.34 & & \pm & $0.04^{c}$ \\
\hline $18: 3 n-3$ & 1.01 & \pm & $0.07^{\mathrm{a}}$ & 0.61 & & \pm & $0.05^{\mathrm{b}}$ & 1.11 & & \pm & $0.12^{\mathrm{a}}$ \\
\hline $20: 3 n-3$ & 0.28 & \pm & $0.02^{\mathrm{a}}$ & 0.17 & & \pm & $0.07^{\mathrm{b}}$ & 0.30 & & \pm & $0.02^{\mathrm{c}}$ \\
\hline $20: 5 n-3$ & 5.2 & \pm & $0.4^{\mathrm{a}}$ & 4.2 & & \pm & $0.3^{\mathrm{c}}$ & 6.2 & & \pm & $0.6^{\mathrm{c}}$ \\
\hline $22: 5 n-3$ & 5.1 & \pm & $0.4^{\mathrm{a}}$ & 2.6 & & \pm & $0.2^{\mathrm{b}}$ & 9.8 & & \pm & $1.4^{\mathrm{c}}$ \\
\hline $22: 6 n-3$ & 82.2 & \pm & $9.0^{\mathrm{a}}$ & 77.3 & & \pm & $8.2^{\mathrm{a}}$ & 107.4 & & \pm & $10.2^{\mathrm{b}}$ \\
\hline \multicolumn{12}{|l|}{ DMA $^{\mathrm{f}}$} \\
\hline $16: 0$ & 6.3 & \pm & $0.5^{\mathrm{a}}$ & 3.7 & & \pm & $0.3^{\mathrm{b}}$ & 7.1 & & \pm & $1.1^{\mathrm{a}}$ \\
\hline $16: 1$ & 0.0 & \pm & 0.0 & 0.0 & & \pm & 0.0 & 0.01 & & \pm & 0.04 \\
\hline 18:0 & 3.7 & \pm & $0.3^{\mathrm{a}}$ & 3.5 & & \pm & $0.5^{\mathrm{a}}$ & 5.0 & & \pm & $1.0^{\mathrm{b}}$ \\
\hline $18: 1$ & 3.9 & \pm & $0.3^{\mathrm{a}}$ & 7.0 & & \pm & $0.5^{\mathrm{b}}$ & 2.7 & & \pm & $0.3^{\mathrm{c}}$ \\
\hline \multirow[t]{2}{*}{ Total } & 300 & \pm & $16^{\mathrm{a}}$ & & 284 & \pm & $18^{\mathrm{a}}$ & & 333 & \pm & $24^{\mathrm{b}}$ \\
\hline & $n=9$ & & & & $n=8$ & & & & $\mathrm{n}=8$ & & \\
\hline
\end{tabular}

LF, Low fat; OA, Oleic acid; SFA, Saturated fatty acid.

${ }^{\mathrm{d}}$ Data are the mean $\pm \mathrm{SD}$ and are $\mu \mathrm{mol} / \mathrm{g}$ wet weight.

${ }^{\mathrm{e}}$ Means with different letters are significantly different $(\mathrm{p}<0.05)$ from values in the same row by one way ANOVA.

${ }^{\mathrm{f}}$ Dimethyl acetal derivatives.

Table 7

Impact of high OA vs high SFA diets on renal neutral lipid fatty acids.

\begin{tabular}{|c|c|c|c|c|c|c|c|c|c|c|c|c|}
\hline \multirow{2}{*}{$\begin{array}{l}\begin{array}{l}\text { Fatty } \\
\text { acid }\end{array} \\
12: 0\end{array}$} & \multicolumn{4}{|c|}{$\begin{array}{l}16 \% \text { Fat Energy } \\
\text { LF }\end{array}$} & \multicolumn{4}{|c|}{$\begin{array}{l}50 \% \text { Fat Energy } \\
\text { High OA }\end{array}$} & \multicolumn{4}{|c|}{$\begin{array}{l}50 \% \text { Fat Energy } \\
\text { High SFA }\end{array}$} \\
\hline & 0.9 & & \pm & $1.1^{\mathrm{ae}}$ & 0.5 & \pm & $0.4^{\mathrm{a}}$ & & 4.7 & \pm & & $3.9^{\mathrm{b}}$ \\
\hline $14: 0$ & 7.2 & & \pm & $5.5^{\mathrm{a}}$ & 4.1 & \pm & $3.0^{\mathrm{a}}$ & & 17.3 & \pm & & $9.4^{\mathrm{b}}$ \\
\hline $16: 0$ & 53.1 & & \pm & $34.3^{\mathrm{a}}$ & 20.9 & \pm & $7.2^{\mathrm{b}}$ & & 41.7 & \pm & & $18.8^{\mathrm{a}}$ \\
\hline 18:0 & 9.3 & & \pm & 4.8 & 6.7 & \pm & 2.3 & & 9.1 & \pm & & 3.0 \\
\hline $20: 0$ & 0.9 & & \pm & $0.5^{\mathrm{a}}$ & 0.4 & \pm & $0.2^{\mathrm{b}}$ & & 0.6 & \pm & & $0.2^{\mathrm{a}, \mathrm{b}}$ \\
\hline 22:0 & 0.23 & & \pm & $0.07^{\mathrm{a}, \mathrm{b}}$ & 0.34 & \pm & $0.13^{\mathrm{b}}$ & & 0.21 & \pm & & $0.03^{\mathrm{a}}$ \\
\hline 24:0 & 0.2 & & \pm & 0.0 & 0.2 & \pm & 0.0 & & 0.2 & \pm & & 0.0 \\
\hline $16: 1 n-7$ & 13.1 & & \pm & $11.9^{\mathrm{a}}$ & 2.0 & \pm & $1.0^{\mathrm{b}}$ & & 7.9 & \pm & & $6.3^{\mathrm{a}}$ \\
\hline $18: 1 n-7$ & 2.8 & & \pm & $2.0^{\mathrm{a}}$ & 1.0 & \pm & $0.4^{\mathrm{b}}$ & & 1.3 & \pm & & $0.7^{\mathrm{a}, \mathrm{b}}$ \\
\hline $18: 1 n-9$ & 79.7 & & \pm & 58.9 & 90.7 & \pm & 43.2 & & 57.5 & \pm & & 32.4 \\
\hline $20: 1 n-9$ & 1.4 & & \pm & 0.8 & 1.2 & \pm & 0.4 & & 1.1 & \pm & & 0.3 \\
\hline $22: 1 n-9$ & 0.2 & & \pm & 0.1 & 0.1 & \pm & 0.1 & & 0.2 & \pm & & 0.0 \\
\hline $18: 2 n-6$ & 24.7 & & \pm & $16.1^{\mathrm{a}}$ & 8.2 & \pm & $3.1^{\mathrm{b}}$ & & 16.2 & \pm & & $7.0^{\mathrm{a}}$ \\
\hline $18: 3 n-6$ & 0.3 & & \pm & 0.1 & 0.1 & \pm & 0.1 & & 0.3 & \pm & & 0.1 \\
\hline $20: 2 n-6$ & 0.19 & & \pm & $0.06^{\mathrm{a}}$ & 0.02 & \pm & $0.04^{\mathrm{b}}$ & & 0.20 & \pm & & $0.02^{\mathrm{a}}$ \\
\hline $20: 3 n-6$ & 0.5 & & \pm & 0.1 & 0.4 & \pm & 0.1 & & 0.6 & \pm & & 0.1 \\
\hline $20: 4 n-6$ & 1.4 & & \pm & 0.2 & 1.2 & \pm & 0.3 & & 1.3 & \pm & & 0.3 \\
\hline $22: 4 n-6$ & 0.1 & & \pm & 0.1 & ND & \pm & ND & & 0.1 & \pm & & 0.1 \\
\hline $18: 3 n-3$ & 7.1 & & \pm & $4.1^{\mathrm{a}}$ & 2.6 & \pm & $1.0^{\mathrm{b}}$ & & 5.2 & \pm & & $2.2^{\mathrm{a}}$ \\
\hline $20: 3 n-3$ & 0.10 & & \pm & $0.10^{\mathrm{a}}$ & ND & \pm & $\mathrm{ND}^{\mathrm{b}}$ & & 0.16 & \pm & & $0.02^{\mathrm{a}}$ \\
\hline $20: 5 n-3$ & 0.7 & & \pm & $0.2^{\mathrm{a}}$ & 0.3 & \pm & $0.1^{\mathrm{b}}$ & & 0.6 & \pm & & $0.2^{\mathrm{a}}$ \\
\hline $22: 5 n-3$ & 1.2 & & \pm & $0.3^{\mathrm{a}}$ & 0.5 & \pm & $0.1^{\mathrm{b}}$ & & 1.5 & \pm & & $0.2^{\mathrm{c}}$ \\
\hline $22: 6 n-3$ & 6.0 & & \pm & $1.5^{\mathrm{a}}$ & 3.8 & \pm & $0.7^{\mathrm{b}}$ & & 6.0 & \pm & & $0.8^{\mathrm{a}}$ \\
\hline \multirow[t]{2}{*}{ Total } & 211.5 & \pm & & 140.6 & 127.2 & \pm & 76.9 & 155.2 & & & \pm & 97.8 \\
\hline & $n=9$ & & & & $n=8$ & & & $n=8$ & & & & \\
\hline
\end{tabular}

LF, Low fat; OA, Oleic acid; SFA, Saturated fatty acid; ND, Not detectable.

${ }^{\mathrm{d}}$ Data are mean $\pm \mathrm{SD}$ and are $\mu \mathrm{mol} / \mathrm{g}$ dry weight.

${ }^{e}$ Means with different letters are significantly different $(\mathrm{p}<0.05)$ from values in the same row by one way ANOVA. 
Table 8

Impact of high OA vs high SFA diets on cardiac phospholipid lipid fatty acids. ${ }^{\mathrm{d}}$

\begin{tabular}{|c|c|c|c|c|c|c|c|c|c|c|}
\hline \multirow{2}{*}{$\begin{array}{l}\text { Fatty } \\
\text { acid }\end{array}$} & \multicolumn{3}{|c|}{$\begin{array}{l}\text { 16\% Fat Energy } \\
\text { LF }\end{array}$} & \multicolumn{4}{|c|}{$\begin{array}{l}50 \% \text { Fat Energy } \\
\text { High OA }\end{array}$} & \multicolumn{3}{|c|}{$\begin{array}{l}\text { 50\% Fat Energy } \\
\text { High SFA }\end{array}$} \\
\hline & 0.01 & \pm & 0.01 & 0.00 & \pm & & 0.00 & 0.05 & \pm & 0.03 \\
\hline $14: 0$ & 0.23 & \pm & $0.07^{\mathrm{ae}}$ & 0.26 & \pm & & $0.06^{\mathrm{a}}$ & 0.49 & \pm & $0.09^{\mathrm{b}}$ \\
\hline $16: 0$ & 10.5 & \pm & 1.6 & 9.7 & \pm & & 1.6 & 10.2 & \pm & 1.6 \\
\hline 18:0 & 14.8 & \pm & 2.7 & 15.4 & \pm & & 2.1 & 16.5 & \pm & 2.7 \\
\hline 20:0 & 0.14 & \pm & $0.04^{\mathrm{a}}$ & 0.14 & \pm & & $0.04^{\mathrm{a}}$ & 0.10 & \pm & $0.02^{\mathrm{b}}$ \\
\hline $22: 0$ & 0.09 & \pm & $0.02^{\mathrm{a}}$ & 0.19 & \pm & & $0.03^{\mathrm{b}}$ & 0.08 & \pm & $0.01^{\mathrm{a}}$ \\
\hline $16: 1 n-7$ & 0.33 & \pm & $0.06^{\mathrm{a}}$ & $0.11 b$ & \pm & & $0.05^{\mathrm{b}}$ & 0.24 & \pm & $0.07^{\mathrm{c}}$ \\
\hline $18: 1 n-7$ & 1.3 & \pm & $0.2^{\mathrm{a}}$ & 1.1 & \pm & & $0.2^{\mathrm{a}, \mathrm{b}}$ & 0.9 & \pm & $0.1^{\mathrm{a}}$ \\
\hline $18: 1 n-9$ & $5.3^{\mathrm{a}}$ & \pm & 0.7 & 9.0 & \pm & & $1.3^{\mathrm{b}}$ & 5.1 & \pm & $0.8^{\mathrm{a}}$ \\
\hline $20: 1 n-9$ & 0.16 & \pm & $0.03^{\mathrm{a}}$ & 0.16 & \pm & & $0.03^{\mathrm{a}}$ & 0.10 & \pm & $0.02^{\mathrm{b}}$ \\
\hline $22: 1 n-9$ & 0.08 & \pm & 0.05 & 0.09 & \pm & & 0.05 & 0.05 & \pm & 0.02 \\
\hline $24: 1 n-9$ & 0.00 & \pm & 0.01 & 0.00 & \pm & & 0.00 & 0.00 & \pm & 0.01 \\
\hline $18: 2 n-6$ & 9.2 & \pm & $1.3^{\mathrm{a}}$ & 5.2 & & \pm & $0.8^{\mathrm{b}}$ & 9.2 & \pm & $1.6^{\mathrm{a}}$ \\
\hline $18: 3 n-6$ & 0.01 & \pm & 0.02 & 0.00 & & \pm & 0.00 & 0.02 & \pm & 0.02 \\
\hline $20: 2 n-6$ & 0.12 & \pm & $0.02^{\mathrm{a}}$ & 0.09 & & \pm & $0.02^{\mathrm{b}}$ & 0.11 & \pm & $0.02^{\mathrm{a}, \mathrm{b}}$ \\
\hline $20: 3 n-6$ & 0.60 & \pm & $0.09^{\mathrm{a}}$ & 0.79 & & \pm & $0.11^{\mathrm{b}}$ & 0.88 & \pm & $0.14^{\mathrm{b}}$ \\
\hline $20: 4 n-6$ & 3.4 & \pm & $1.4^{\mathrm{a}}$ & 4.2 & & \pm & $0.5^{\mathrm{a}}$ & 5.6 & \pm & $0.8^{\mathrm{b}}$ \\
\hline $22: 4 n-6$ & 0.09 & \pm & $0.02^{\mathrm{a}}$ & 0.06 & & \pm & $0.03^{\mathrm{a}}$ & 0.12 & \pm & $0.02^{\mathrm{b}}$ \\
\hline $22: 5 n-6$ & 0.15 & \pm & $0.04^{\mathrm{a}, \mathrm{b}}$ & 0.12 & & \pm & $0.03^{\mathrm{a}}$ & 0.19 & \pm & $0.03^{\mathrm{b}}$ \\
\hline $18: 3 n-3$ & 0.25 & \pm & $0.03^{\mathrm{a}}$ & 0.15 & & \pm & $0.03^{\mathrm{b}}$ & 0.24 & \pm & $0.04^{\mathrm{a}}$ \\
\hline $20: 3 n-3$ & 0.04 & \pm & 0.02 & 0.00 & & \pm & 0.01 & 0.88 & \pm & 0.14 \\
\hline $20: 5 n-3$ & 0.22 & \pm & $0.04^{\mathrm{a}}$ & 0.19 & & \pm & $0.04^{\mathrm{a}}$ & 0.27 & \pm & $0.03^{\mathrm{b}}$ \\
\hline $22: 5 n-3$ & 1.8 & \pm & $0.3^{\mathrm{a}}$ & 1.3 & & \pm & $0.1^{\mathrm{b}}$ & 2.6 & \pm & $0.4^{\mathrm{c}}$ \\
\hline $22: 6 n-3$ & 21.5 & \pm & 2.9 & 23.4 & & \pm & 3.7 & 20.2 & \pm & 3.8 \\
\hline \multicolumn{11}{|l|}{ DMA $^{\mathrm{f}}$} \\
\hline $16: 0$ & 1.6 & \pm & $0.4^{\mathrm{a}}$ & 1.2 & & \pm & $0.2^{\mathrm{b}}$ & 1.6 & \pm & $0.4^{\mathrm{a}, \mathrm{b}}$ \\
\hline $16: 1$ & 0.01 & \pm & 0.01 & 0.00 & & \pm & 0.00 & 0.01 & \pm & 0.01 \\
\hline 18:0 & 1.0 & \pm & 0.2 & 1.1 & & \pm & 0.2 & 1.2 & \pm & 0.3 \\
\hline $18: 1$ & 0.51 & \pm & $0.11^{\mathrm{a}}$ & 1.20 & & \pm & $0.20^{\mathrm{b}}$ & 0.32 & \pm & $0.07^{\mathrm{c}}$ \\
\hline \multirow[t]{2}{*}{ Total } & 73.5 & \pm & 9.8 & 75.0 & & \pm & 10.5 & 76.4 & \pm & 12.4 \\
\hline & $n=8$ & & & $n=7$ & & & & $n=7$ & & \\
\hline
\end{tabular}

LF, Low fat; OA, Oleic acid; SFA, Saturated fatty acid.

${ }^{\mathrm{d}}$ Data are the mean $\pm \mathrm{SD}$ and are $\mu \mathrm{mol} / \mathrm{g}$ wet weight.

${ }^{\mathrm{e}}$ Means with different letters are significantly different $(\mathrm{p}<0.05)$ from values in the same row by one way ANOVA.

${ }^{\mathrm{f}}$ Dimethyl acetal derivatives.

Table 9

Impact of high OA vs high SFA diets on cardiac neutral lipid fatty acids. ${ }^{c}$

\begin{tabular}{|c|c|c|c|c|c|c|c|c|c|c|}
\hline \multirow{2}{*}{$\begin{array}{l}\text { Fatty } \\
\text { acid }\end{array}$} & \multicolumn{3}{|c|}{$\begin{array}{l}\text { 16\% Fat Energy } \\
\text { LF }\end{array}$} & \multicolumn{3}{|c|}{$\begin{array}{l}50 \% \text { Fat Energy } \\
\text { High OA }\end{array}$} & \multicolumn{4}{|c|}{$\begin{array}{l}50 \% \text { Fat Energy } \\
\text { High SFA }\end{array}$} \\
\hline & 0.06 & \pm & $0.05^{\mathrm{ad}}$ & 0.04 & \pm & 0.05 & 0.41 & \pm & & 0.49 \\
\hline $14: 0$ & 0.79 & \pm & $0.45^{\mathrm{a}, \mathrm{b}}$ & 0.42 & \pm & $0.12^{\mathrm{a}}$ & 1.65 & \pm & & $1.27^{\mathrm{b}}$ \\
\hline $16: 0$ & 9.2 & \pm & $5.4^{\mathrm{a}}$ & 4.0 & \pm & $0.8^{\mathrm{b}}$ & 6.6 & \pm & & $3.2^{\mathrm{a}, \mathrm{b}}$ \\
\hline 18:0 & 2.6 & \pm & 1.3 & 2.3 & \pm & 0.6 & 2.1 & \pm & & 0.5 \\
\hline 20:0 & 0.17 & \pm & 0.09 & 0.12 & \pm & 0.04 & 0.12 & \pm & & 0.03 \\
\hline $22: 0$ & 0.05 & \pm & $0.02^{\mathrm{a}}$ & 0.11 & \pm & $0.03^{\mathrm{b}}$ & 0.06 & \pm & & $0.01^{\mathrm{a}}$ \\
\hline $16: 1 n-7$ & 2.1 & \pm & $1.4^{\mathrm{a}}$ & 0.3 & \pm & $0.1^{\mathrm{b}}$ & 1.1 & \pm & & $0.7^{\mathrm{a}}$ \\
\hline $18: 1 n-7$ & 0.56 & \pm & $0.25^{\mathrm{a}}$ & 0.21 & \pm & $0.05^{\mathrm{b}}$ & 0.30 & \pm & & $0.11^{\mathrm{b}}$ \\
\hline $18: 1 n-9$ & 14.3 & \pm & 7.2 & 14.7 & \pm & 6.2 & 11.2 & \pm & & 5.8 \\
\hline $20: 1 n-9$ & 0.30 & \pm & $0.10^{\mathrm{a}}$ & 0.11 & \pm & $0.03^{\mathrm{b}}$ & 0.23 & \pm & & $0.07^{\mathrm{a}, \mathrm{b}}$ \\
\hline $22: 1 n-9$ & 0.11 & \pm & 0.05 & 0.00 & \pm & 0.00 & 0.08 & \pm & & 0.01 \\
\hline $18: 2 n-6$ & 3.7 & \pm & $1.2^{\mathrm{a}}$ & 1.5 & \pm & $0.3^{\mathrm{b}}$ & 3.1 & \pm & & $1.2^{\mathrm{a}}$ \\
\hline $18: 3 n-6$ & 0.01 & \pm & 0.02 & 0.00 & \pm & 0.01 & 0.03 & \pm & & 0.02 \\
\hline $20: 2 n-6$ & 0.04 & \pm & $0.02^{\mathrm{a}}$ & 0.00 & \pm & $0.01^{\mathrm{b}}$ & 0.01 & \pm & $0.01^{\mathrm{a}, \mathrm{b}}$ & \\
\hline $20: 3 n-6$ & 0.10 & \pm & 0.02 & 0.09 & \pm & 0.02 & 0.12 & \pm & 0.02 & \\
\hline $20: 4 n-6$ & 0.23 & \pm & 0.08 & 0.20 & \pm & 0.05 & 0.24 & \pm & 0.04 & \\
\hline $22: 4 n-6$ & 0.04 & \pm & $0.02^{\mathrm{a}}$ & 0.01 & \pm & $0.01^{\mathrm{b}}$ & 0.05 & \pm & $0.01^{\mathrm{a}}$ & \\
\hline $18: 3 n-3$ & 0.71 & \pm & $0.27^{\mathrm{a}}$ & 0.34 & \pm & $0.12^{\mathrm{b}}$ & 0.68 & \pm & $0.31^{\mathrm{a}}$ & \\
\hline $20: 3 n-3$ & 0.00 & \pm & 0.00 & 0.00 & \pm & 0.00 & 0.00 & \pm & 0.00 & \\
\hline $20: 5 n-3$ & 0.06 & \pm & $0.03^{\mathrm{a}}$ & 0.01 & \pm & $0.02^{\mathrm{b}}$ & 0.07 & \pm & $0.01^{\mathrm{a}}$ & \\
\hline $22: 5 n-3$ & 0.49 & \pm & $0.10^{\mathrm{a}}$ & 0.33 & \pm & $0.07^{\mathrm{b}}$ & 0.60 & \pm & $0.07^{\mathrm{a}, \mathrm{b}}$ & \\
\hline $22: 6 n-3$ & 0.65 & \pm & 0.15 & 0.72 & \pm & 0.18 & 0.70 & \pm & 0.07 & \\
\hline \multirow[t]{2}{*}{ Total } & 36.2 & \pm & 17.3 & 25.6 & \pm & 7.7 & 29.5 & \pm & 13.6 & \\
\hline & $n=8$ & & & $n=7$ & & & $n=7$ & & & \\
\hline
\end{tabular}

LF, Low fat; OA, Oleic acid; SFA, Saturated fatty acid.

${ }^{c}$ Data are mean \pm SD and are $\mu \mathrm{mol} / \mathrm{g}$ wet weight.

${ }^{\mathrm{d}}$ Means with different letters are significantly different $(\mathrm{p}<0.05)$ from values in the same row by one way ANOVA. 
Table 10

Impact of high OA vs high SFA diets on epididymal adipose fatty acids. ${ }^{\mathrm{d}}$

\begin{tabular}{|c|c|c|c|c|c|c|c|c|c|}
\hline \multirow{2}{*}{$\begin{array}{l}\text { Fatty } \\
\text { acid }\end{array}$} & \multicolumn{3}{|c|}{$\begin{array}{l}\text { 16\% Fat Energy } \\
\text { LF }\end{array}$} & \multicolumn{3}{|c|}{$\begin{array}{l}50 \% \text { Fat Energy } \\
\text { High OA }\end{array}$} & \multicolumn{3}{|c|}{$\begin{array}{l}50 \% \text { Fat Energy } \\
\text { High SFA }\end{array}$} \\
\hline & 64.3 & \pm & $9.6^{\mathrm{a}, \mathrm{e}}$ & 43.4 & \pm & $0.4^{\mathrm{b}}$ & 416 & \pm & $3.6^{\mathrm{c}}$ \\
\hline $14: 0$ & 97.8 & \pm & $12.8^{\mathrm{a}}$ & 63.0 & \pm & $4.3^{\mathrm{b}}$ & 370 & \pm & $40^{c}$ \\
\hline $16: 0$ & 794 & \pm & $135^{\mathrm{a}}$ & 462 & \pm & $7.7^{\mathrm{b}}$ & 949 & \pm & $34^{\mathrm{c}}$ \\
\hline 18:0 & 59.6 & \pm & $11.0^{\mathrm{a}}$ & 64.3 & \pm & $74^{\mathrm{b}}$ & 103.3 & \pm & $93^{c}$ \\
\hline 20:0 & 2.9 & \pm & $0.5^{\mathrm{a}}$ & 2.0 & \pm & $0.3^{\mathrm{b}}$ & 2.7 & \pm & $0.2^{\mathrm{a}}$ \\
\hline 22:0 & 1.1 & \pm & $0.3^{\mathrm{a}}$ & 1.6 & \pm & $0.3^{\mathrm{b}}$ & 0.6 & \pm & $0.2^{\mathrm{a}}$ \\
\hline 24:0 & 0.5 & \pm & $0.1^{\mathrm{a}}$ & 0.5 & \pm & $0.4^{\mathrm{a}}$ & ND & \pm & $\mathrm{ND}^{\mathrm{b}}$ \\
\hline $12: 1 n-7$ & 1.5 & \pm & $0.2^{\mathrm{a}}$ & 0.8 & \pm & $0.1^{\mathrm{b}}$ & 8.1 & \pm & $0.7^{\mathrm{c}}$ \\
\hline $14: 1 n-7$ & 6.2 & \pm & $1.1^{\mathrm{a}}$ & 2.1 & \pm & $0.4^{\mathrm{b}}$ & 29.4 & \pm & $3.5^{\mathrm{c}}$ \\
\hline $16: 1 n-7$ & 311 & \pm & $43^{\mathrm{a}}$ & 104 & \pm & $13^{\mathrm{b}}$ & 366 & \pm & $37^{\mathrm{c}}$ \\
\hline $18: 1 n-7$ & 56.9 & \pm & $11.2^{\mathrm{a}}$ & 25.4 & \pm & $4.3^{\mathrm{b}}$ & 35.1 & \pm & $4.9^{\mathrm{c}}$ \\
\hline $18: 1 n-9$ & 1717 & \pm & $266^{\mathrm{a}}$ & 3187 & \pm & $416^{b}$ & 1663 & \pm & $116^{\mathrm{a}}$ \\
\hline $20: 1 n-9$ & 21.2 & \pm & $3.1^{\mathrm{a}}$ & 16.1 & \pm & $2.3^{\mathrm{b}}$ & 13.6 & \pm & $1.0^{\mathrm{c}}$ \\
\hline $22: 1 n-9$ & 1.4 & \pm & $0.2^{\mathrm{a}}$ & 0.8 & \pm & $0.2^{\mathrm{b}}$ & 1.0 & \pm & $0.1^{\mathrm{a}, \mathrm{b}}$ \\
\hline $18: 2 n-6$ & 794 & \pm & $177^{\mathrm{a}}$ & 339 & \pm & $49^{\mathrm{b}}$ & 498 & \pm & $74^{\mathrm{c}}$ \\
\hline $18: 3 n-6$ & 6.2 & \pm & $1.0^{\mathrm{a}}$ & 3.0 & \pm & $0.3^{\mathrm{b}}$ & 4.8 & \pm & $0.5^{\mathrm{c}}$ \\
\hline $20: 2 n-6$ & 3.5 & \pm & $0.8^{\mathrm{a}}$ & 1.7 & \pm & $0.2^{\mathrm{b}}$ & 2.4 & \pm & $0.5^{\mathrm{c}}$ \\
\hline $20: 3 n-6$ & 3.7 & \pm & 0.8 & 2.3 & \pm & $0.3^{\mathrm{b}}$ & 3.1 & \pm & $0.4^{\mathrm{a}}$ \\
\hline $20: 4 n-6$ & 5.4 & \pm & $1.2^{\mathrm{a}}$ & 3.3 & \pm & $0.6^{\mathrm{b}}$ & 4.5 & \pm & $0.7^{\mathrm{a}}$ \\
\hline $18: 3 n-3$ & 220 & \pm & $31^{\mathrm{a}}$ & 87 & \pm & $8^{\mathrm{b}}$ & 145 & \pm & $14^{\mathrm{a}, \mathrm{b}}$ \\
\hline $20: 3 n-3$ & 1.3 & \pm & $0.3^{\mathrm{a}}$ & 0.1 & \pm & $0.1^{\mathrm{b}}$ & 0.8 & \pm & $0.5^{\mathrm{a}}$ \\
\hline $20: 5 n-3$ & 3.7 & \pm & $0.7^{\mathrm{a}}$ & 1.7 & \pm & $0.2^{\mathrm{b}}$ & 2.8 & \pm & $0.4^{\mathrm{c}}$ \\
\hline $22: 5 n-3$ & 4.8 & \pm & $1.3^{\mathrm{a}}$ & 2.2 & \pm & $0.4^{\mathrm{b}}$ & 3.7 & \pm & $0.5^{\mathrm{c}}$ \\
\hline \multirow[t]{2}{*}{$22: 6 n-3$} & 7.6 & \pm & $1.6^{\mathrm{a}}$ & 5.3 & \pm & $0.9^{\mathrm{b}}$ & 5.4 & \pm & $1.1^{\mathrm{b}}$ \\
\hline & $n=9$ & & & $n=8$ & & & $n=8$ & & \\
\hline
\end{tabular}

LF, Low fat; OA, Oleic acid; SFA, Saturated fatty acid.

${ }^{\mathrm{d}}$ Data are mean \pm SD and are $\mu \mathrm{mol} / \mathrm{g}$ wet weight.

${ }^{\mathrm{e}}$ Means with different letters are significantly different $(\mathrm{p}<0.05)$ from values in the same row by one way ANOVA.

table showing the hepatic oxylipins observed and their parent fatty acids is provided in Supplementary Table 1.

In adipose tissue, 19 oxylipin were detected, of which 7 were changed by consumption of the high fat diet (Fig. 5). The 9-hydroxy and 13-hydroxy derivatives of LA and ALA were reduced from animals fed the high OA diet. Moreover, the poly-oxygenated metabolites of LA, comprised of 9,10,13-trihydroxyoctaenoic acid (9,10,13-triHOME), 9,10-dihydroxy octaenoic acid (9,10-DiHOME) and 12,13-DiHOME, were reduced by consumption of the high OA diet compared to controls. None of the adipose oxylipin analytes were altered by

Table 11

Impact of high OA vs high SFA diets on total epididymal adipose pool of fatty acids. ${ }^{\mathrm{d}}$

\begin{tabular}{|c|c|c|c|c|c|c|c|c|c|}
\hline \multirow{2}{*}{$\begin{array}{l}\text { Fatty } \\
\text { acid }\end{array}$} & \multicolumn{3}{|c|}{$\begin{array}{l}\text { 16\% Fat Energy } \\
\text { LF }\end{array}$} & \multicolumn{3}{|c|}{$\begin{array}{l}50 \% \text { Fat Energy } \\
\text { High OA }\end{array}$} & \multicolumn{3}{|c|}{$\begin{array}{l}50 \% \text { Fat Energy } \\
\text { High SFA }\end{array}$} \\
\hline & 74 & \pm & $23^{\mathrm{a}, \mathrm{e}}$ & 73 & \pm & $16^{\mathrm{a}}$ & 694 & \pm & $145^{\mathrm{b}}$ \\
\hline $14: 0$ & 113 & \pm & $35^{\mathrm{a}}$ & 107 & \pm & $27^{\mathrm{a}}$ & 623 & \pm & $151^{\mathrm{b}}$ \\
\hline $16: 0$ & 931 & \pm & $337^{\mathrm{a}}$ & 790 & \pm & $234^{\mathrm{a}}$ & 1609 & \pm & $439^{b}$ \\
\hline $18: 0$ & 70 & \pm & $24^{\mathrm{a}}$ & 110 & \pm & $32^{\mathrm{b}}$ & 174 & \pm & $43^{c}$ \\
\hline $20: 0$ & 3.2 & \pm & $0.8^{\mathrm{a}}$ & 3.4 & \pm & $1.0^{\mathrm{a}, \mathrm{b}}$ & 4.5 & \pm & $0.9^{\mathrm{b}}$ \\
\hline $22: 0$ & 1.2 & \pm & $0.5^{\mathrm{a}}$ & 2.6 & \pm & $0.8^{\mathrm{b}}$ & 0.5 & \pm & $0.7^{\mathrm{a}}$ \\
\hline $24: 0$ & 0.2 & \pm & $0.3^{\mathrm{a}}$ & 0.9 & \pm & $0.3^{\mathrm{b}}$ & 0.00 & \pm & $0.00^{\mathrm{c}}$ \\
\hline $12: 1 n-7$ & 1.7 & \pm & $0.5^{\mathrm{a}}$ & 1.4 & \pm & $0.3^{\mathrm{a}}$ & 13.5 & \pm & $2.8^{\mathrm{b}}$ \\
\hline $14: 1 n-7$ & 7.1 & \pm & $2.0^{\mathrm{a}}$ & 3.5 & \pm & $1.1^{\mathrm{b}}$ & 49.2 & \pm & $11.3^{\mathrm{c}}$ \\
\hline $16: 1 n-7$ & 363 & \pm & $127^{\mathrm{a}}$ & 176 & \pm & $44^{\mathrm{b}}$ & 617 & \pm & $162^{\mathrm{c}}$ \\
\hline $18: 1 n-7$ & 68 & \pm & 29 & 44 & \pm & 14 & 59 & \pm & 17 \\
\hline $18: 1 n-9$ & 2000 & \pm & $677^{\mathrm{a}}$ & 5427 & \pm & $1484^{\mathrm{b}}$ & 2796 & \pm & $652^{c}$ \\
\hline $20: 1 n-9$ & 24 & \pm & 7 & 28 & \pm & 8 & 23 & \pm & 5 \\
\hline $22: 1 n-9$ & 1.6 & \pm & 0.4 & 1.4 & \pm & 0.5 & 1.6 & \pm & 0.3 \\
\hline $18: 2 n-6$ & 930 & \pm & $351^{\mathrm{a}}$ & 577 & \pm & $163^{\mathrm{b}}$ & 835 & \pm & $221^{\mathrm{a}, \mathrm{b}}$ \\
\hline $18: 3 n-6$ & 7.2 & \pm & $2.4^{\mathrm{a}, \mathrm{b}}$ & 5.0 & \pm & $1.2^{\mathrm{a}}$ & 8.2 & \pm & $2.2^{\mathrm{b}}$ \\
\hline $20: 2 n-6$ & 4.2 & \pm & 1.8 & 2.9 & \pm & 0.7 & 4.1 & \pm & 1.2 \\
\hline $20: 3 n-6$ & 4.5 & \pm & 1.9 & 3.8 & \pm & 1.1 & 5.2 & \pm & 1.4 \\
\hline $20: 4 n-6$ & 6.4 & \pm & 2.7 & 5.7 & \pm & 1.6 & 7.6 & \pm & 2.3 \\
\hline $18: 3 n-3$ & 254 & \pm & $79^{\mathrm{a}}$ & 148 & \pm & $35^{\mathrm{b}}$ & 246 & \pm & $67^{\mathrm{a}}$ \\
\hline $20: 3 n-3$ & 1.5 & \pm & $1.0^{\mathrm{a}}$ & 0.1 & \pm & $0.4^{\mathrm{b}}$ & 1.4 & \pm & $0.9^{\mathrm{a}}$ \\
\hline $20: 5 n-3$ & 4.4 & \pm & $1.7^{\mathrm{a}}$ & 2.8 & \pm & $0.5^{\mathrm{b}}$ & 4.7 & \pm & $1.5^{\mathrm{a}}$ \\
\hline $22: 5 n-3$ & 5.8 & \pm & $2.6^{\mathrm{a}, \mathrm{b}}$ & 3.7 & \pm & $1.1^{\mathrm{a}}$ & 6.3 & \pm & $1.8^{\mathrm{b}}$ \\
\hline \multirow[t]{2}{*}{$22: 6 n-3$} & 8.9 & \pm & 3.5 & 8.8 & \pm & 1.6 & 9.1 & \pm & 2.6 \\
\hline & $n=9$ & & & $n=8$ & & & $n=8$ & & \\
\hline
\end{tabular}

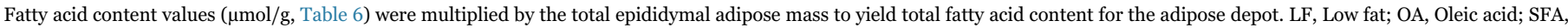
Saturated fatty acid.

${ }^{\mathrm{d}}$ Data are mean $\pm \mathrm{SD}$.

${ }^{e}$ Means with different letters are significantly different $(\mathrm{p}<0.05)$ from values in the same row by one way ANOVA. 

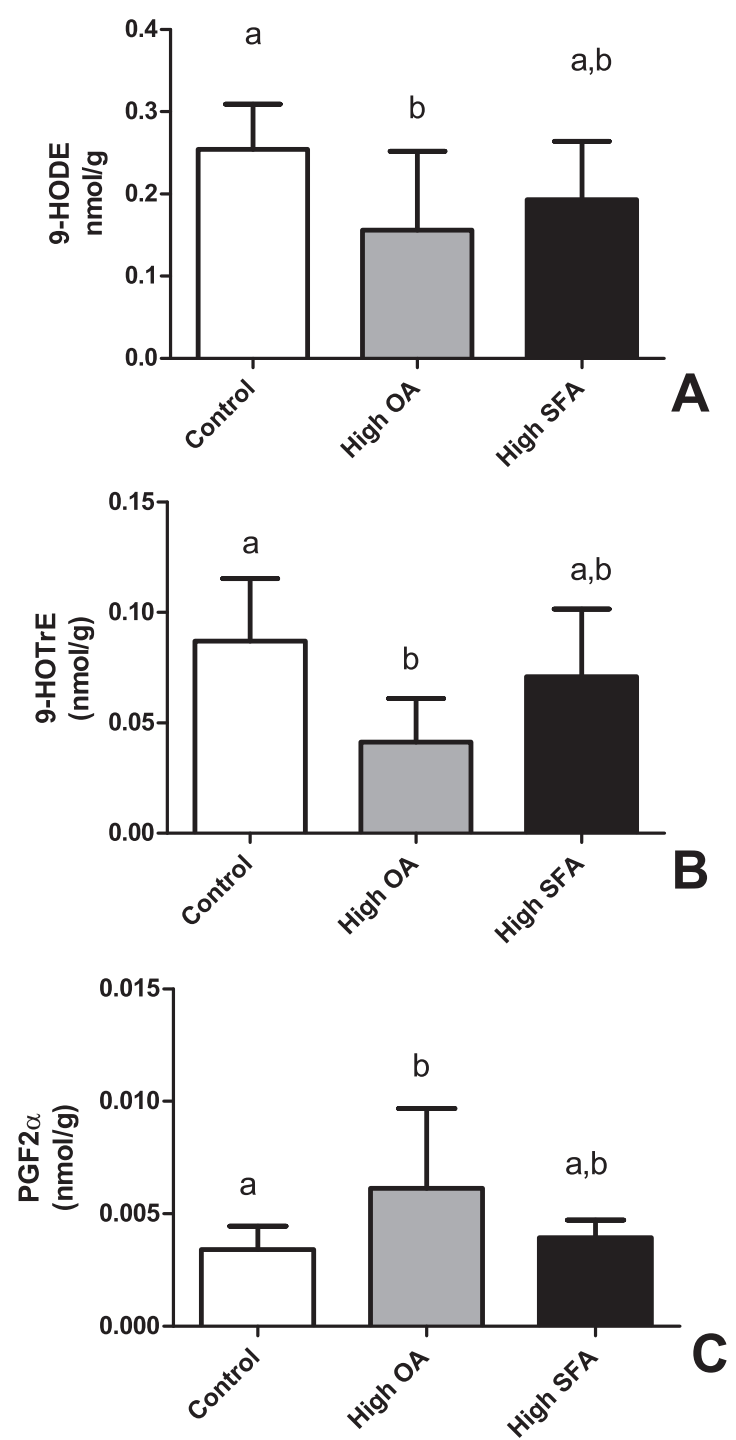

Fig. 4. High OA diet reduces hepatic LA-derived and ALA derived oxylipins

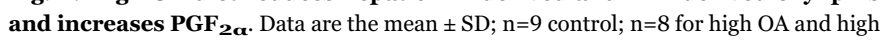
SFA diets Data were compared using a one-way ANOVA with Tukey's contrasts. Columns with different letters are significantly different, $\mathrm{p} \leq 0.05$. HODE; Hydroxyoctadecadienoic acid; HOTrE, Hydroxyoctadecatrienoic acid; LF, Low fat; OA, Oleic acid; SFA, Saturated fatty acid.

consumption of the high SFA diet. A comprehensive table of the adipose oxylipins observed is provided in Supplementary Table 2.

\section{Discussion}

Studies indicate that obesity may impair the synthesis of LCPUFA from dietary ALA and LA [12,13]. The extent to which the nonessential fatty acid (SFA and MUFA) components of obesogenic diets impact PUFA metabolism is not clear. Therefore we examined whether obesogenic diets made with SFA vs OA had different impacts on LCPUFA metabolism. A strength of this current work is that the animals consumed identical amounts of ALA and LA between all three groups. Thus, changes in PUFA metabolic endpoints are not attributable to differences in dietary PUFA but rather to OA and SFA content.

That non-essential fatty acids like OA and SFA impact the metabolism of PUFA was recognized with respect to induction of PUFA deficiency in growing animals $[20,21,35]$. In all peripheral organs we examined, the content of LA and ALA was reduced by intake of a high OA diet but not a diet made with high SFA. These decrements of ALA and LA did not translate into reductions in the tissue content of their respective elongated n-3 and n-6 LCPUFA, DHA and ARA, in liver and heart. Surprisingly, the high SFA diet led to selective increases in LC PUFA, namely hepatic NL-esterified DHA, renal PL-esterified DHA and ARA, and cardiac PL-esterified ARA. The causes for these SFA-induced elevations are not clear.

The accumulation of DHA and ARA in the hepatic NL pool in high OA-treated animals may reflect a decrease in TAG export from the liver given the elevated hepatic TAG content. Previous data indicate that infusion of OA reduces very low density lipoprotein (VLDL) secretion from the liver [36]. The physiological impact of elevated DHA in the NL fraction of high OA-fed mice is not clear. While the liver is considered a major site for the synthesis and export of DHA, the rat heart, on the other hand, has very limited ability to synthesize DHA and must obtain DHA from the plasma [37]. That cardiac levels of DHA were not impacted by the high OA diet suggests that the accumulation of DHA in the hepatic NL fraction may not be rate limiting for distribution to other tissues.

Our data indicate that the high OA, obesogenic diet affected renal PUFA metabolism. In the kidney, decreases in NL-esterified n-3 PUFA (DHA, ALA, and intermediates) and n-6 PUFA (LA and intermediates) occurred. Similarly, while renal PL-esterified DHA and ARA were not altered, levels of 20 carbon n-3 intermediates (in addition to ALA) and ARA precursors were reduced. It is not clear why there was a selective reduction of DHA, but not ARA, in the NL fraction. Subsequent study is needed to determine the extent to which PUFA elongation and desaturation products synthesized within the kidney are reduced vs those obtained acquired from plasma lipoproteins, e.g. from hepatic export or chylomicrons.

It is generally held and clinical data support that adipose tissue fatty acid composition reflects the fatty acid of the diet $[38,39]$. While our data do show that the SFA and MUFA content of the adipose tissue reflects that of the diet, this observation does not apply to PUFA. Our observations indicate that even under conditions of constant PUFA intake, PUFA composition of visceral (epididymal) adipose tissue is modifiable by intake of the obesogenic diets and by the OA content of those diets. We hypothesize that at least two separate mechanisms exist that lead to reductions in adipose PUFA. The first mechanism represents dilution of PUFA by the higher levels of MUFA and SFA during adipose expansion. This may account for the observed decreases in PUFA when expressed as a mol fatty acid / gram adipose and normalization of these decreases when expressed as the total adipose mass for the high SFA group. That ALA and LA levels in the high OA diet groups were reduced compared to the SFA group under both conditions indicates an inhibition of LA and ALA uptake into the adipose tissue.

That there can be competitive inhibition of LA and ALA uptake into cells is supported by the fact that the fatty acid transporter CD36 transports OA with a lower $\mathrm{K}_{\mathrm{M}}(60 \mathrm{nM})$ than for linoleic acid $(220 \mathrm{nM})$, although the $K_{M}$ for ALA has not been reported [40]. This transporter is expressed in a number of cell types including adipocytes, enterocytes, and fibroblasts [41-43]. The extent to which there is competition for incorporation into specific lipid pools intracellularly is not clear. In vivo tracer studies using labeled ALA and LA and in vitro experiments are needed to confirm these mechanisms.

In addition to basic fatty acid endpoints, we examined whether downstream PUFA metabolism to oxylipins was influenced by fatty acid content of the diet. Oxylipins derived from the oxidation of LA and ALA have biological activity in vitro and their levels can be modified by dietary ALA and LA content $[14,16,44,45]$ in vivo. In humans, plasma levels of 9HODE and 13-HODE are elevated with hepatic steatosis and decrease following weight loss [46]. Our data indicate that the hepatic and adipose levels of 9-HODE (derived from LA) and 9-HOTrE (derived from ALA) and other oxylipins are reduced by dietary MUFA under high-fat conditions even though hepatic lipids and blood glucose are elevated. As such, the extent that these oxidation products are related to the development of fatty liver and insulin resistance is not clear. 

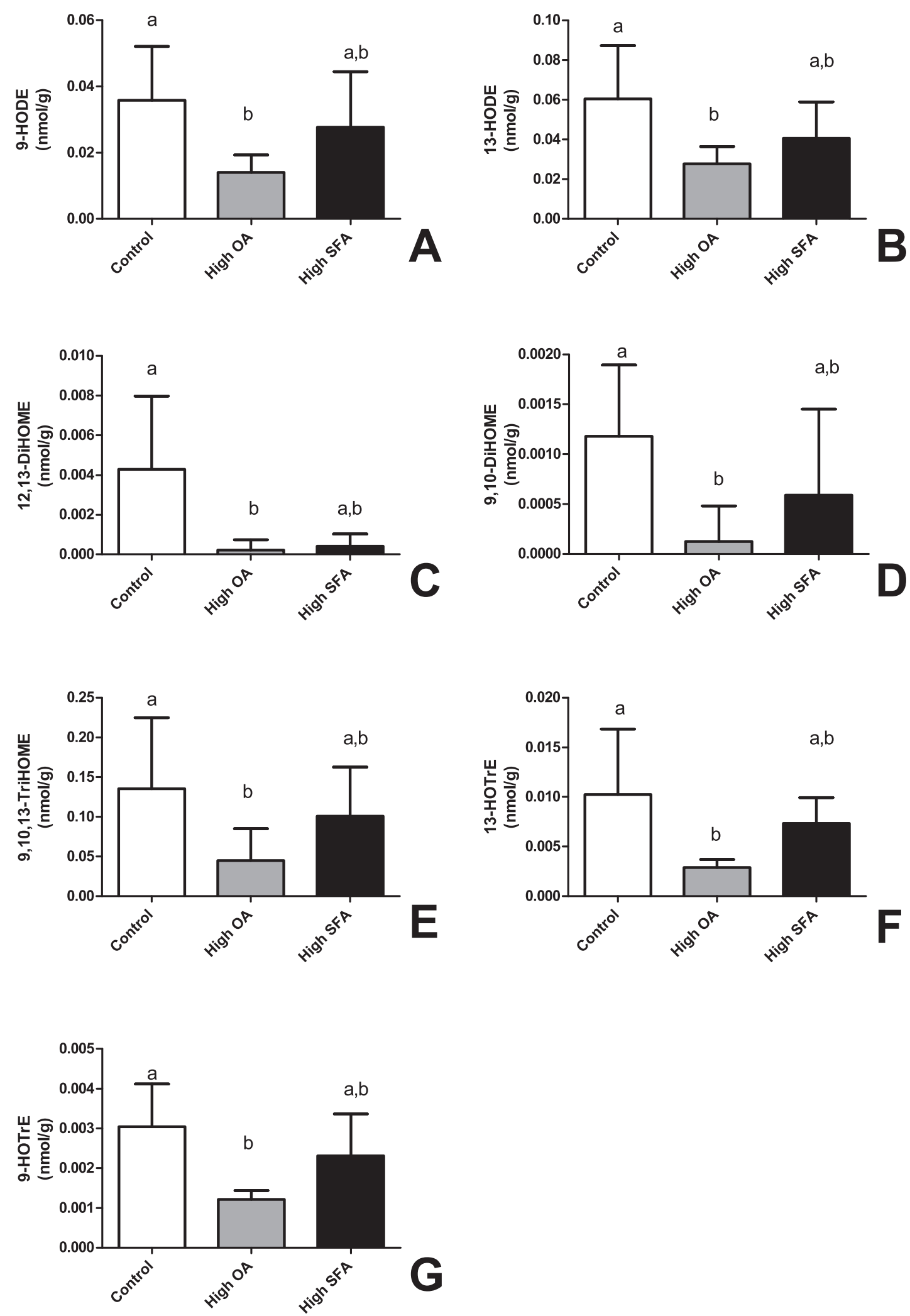

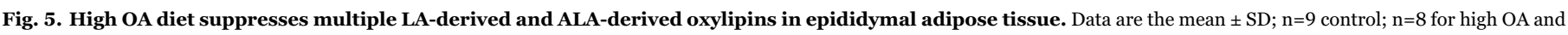

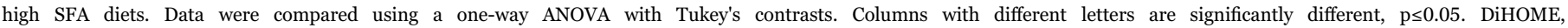

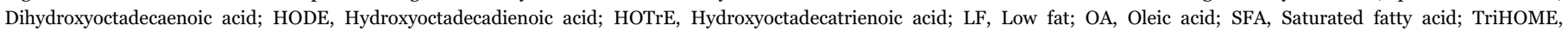
Trihydroxyoctadecaenoic acid.

While the data point to decreases in tissue content of LA and ALA as initial causes of lower levels of these oxylipins, other explanations may exist. We cannot exclude that there is a decrease in the rate of formation or an increase in the rate of clearance of these oxylipins. It is unlikely that changes in adipose content are a simple influence of mass balance given that adipose levels of LA and ALA are magnitudes higher 
than in liver yet the adipose content of 9-HODE and 9-HOTrE are 10fold lower than in liver. As these oxylipins are observed in the plasma, the adipose content of these oxylipins may be a function of accumulation from the plasma compartment $[15,47]$.

The elevation of hepatic levels of $\mathrm{PGF}_{2 \alpha}$ in animals consuming the high $\mathrm{OA}$ diet was the only change in the prostanoid endpoints observed. The increase in hepatic $\mathrm{PGF}_{2 \alpha}$ is intriguing as $\mathrm{PGF}_{2 \alpha}$ modifies hepatic glucose metabolism [48-50]. Some studies have shown that $\mathrm{PGF}_{2 a}$ released from Kuppfer cells blocks glycogenolysis through inhibition of glucagon-stimulated cAMP formation [50]. Rat hepatocytes express receptors for the $\mathrm{PGF}_{2 \alpha}$ receptor with a $\mathrm{K}_{\mathrm{D}}$ of $3 \mathrm{nM}$, a concentration similar to the tissue levels of $\mathrm{PGF}_{2 \alpha}$ detected in our murine liver samples [51,52].

Changes in hepatic CL fatty acid composition influence the activity of several mitochondrial enzymes [34,53,54]. Although the level of PLesterified LA was reduced by the high OA diet, we were surprised to observe that the percent of CL-esterified LA was not changed whereas the content of OA and ARA were elevated. The high SFA diet increased the desaturation level of CL by increasing ARA and DHA while reducing palmitate content. These data indicate that both high-fat diets increased the level of unsaturated fatty acids in the CL fraction. Higher level of unsaturation of mitochondrial PLs is associated with increased mitochondrial uncoupling rates and fatty acid oxidation rates and may underlie in part an adaptation to increase fatty acid utilization for energy [34].

The differences in hepatic TAG content were striking given the fact that both diets contained the same energy as fat and that both obesogenic diets induced the same level of weight gain and increase in adiposity. Several mechanisms may underlie this result including OA-induced decreases in hepatic VLDL secretion, changes in fatty acid oxidation and elevated fatty acid inputs either from de novo lipogenesis or from plasma free fatty acids $[36,55,56]$. Similar to our work, Buettner and colleagues demonstrated that intake of an obesogenic diet made with coconut oil promotes insulin sensitivity and elevates adiposity. In that study, however, hepatic TAG content was elevated vs controls, unlike our results, perhaps as a result of the near total lack of PUFA in the coconut oil-based diet used in that study [5].

Our data indicate that more study is needed to evaluate the health roles of medium chain SFA. Multiple studies have used the medium chain SFA octanoic acid (8:0) and decanoic acid (10:0) to show a protective effect against obesity in humans and reduces steatosis in a rodent model $[3,57,58]$. Our diet contained only minor amounts of decanoic acid. However, the high SFA diet did contain significant amounts of lauric acid (12:0) which has properties of both MCT and longer chain SFA and undergoes chylomicron transport to adipose [58]. Subsequent research is needed to determine how specific SFAs impact the development of hepatic steatosis. In our study we chose to SFA that comprised the spectrum of SFA eaten worldwide [59]. While 12:0 is not common is the western diet, the use of coconut oil is increasing, and moreover, levels of obesity are increasing in Middle Eastern and Asian countries [1,60].

In our study we chose to use high fat, hypercaloric diets that are typically used in mechanistic studies to induce obesity in rodents. We recognize that total amount of fat energy ( $50 \%$ en) in the diets is higher than median reported intake (35\% en) for Americans (2013-2014 NHANES) and as such have a higher percent of calories from OA, total SFA, and palmitic acid [59]. With dietary guidelines emphasizing the reduction of SFA intake [6] and efforts to replace PUFA with OA in dietary oils [61], our results indicate the need for greater study of the impact of OA and SFA at differing intake levels upon PUFA metabolism and hepatic lipid metabolism.

\section{Acknowledgements}

The authors thank LuAnn Johnson, Deborah Johnson, Brian Gregoire and the GFHRNC vivarium staff for their excellent technical assistance. The U.S. Department of Agriculture, Agricultural Research Service, Plains Area is an equal opportunity/affirmative action employers and all agency services are available without discrimination.
Mention of trade names or commercial products in this article is solely for providing specific information and does not imply recommendation or endorsement by the U.S. Department of Agriculture.

\section{Appendix A. Supplementary material}

Supplementary data associated with this article can be found in the online version at doi:10.1016/j.plefa.2017.03.001.

\section{References}

[1] M. Ng, T. Fleming, M. Robinson, B. Thomson, N. Graetz, et al., Global, regional, and national prevalence of overweight and obesity in children and adults during 1980-2013: a systematic analysis for the Global burden of disease study 2013, Lancet 384 (2014) 766-781.

[2] C.L. Ogden, M.D. Carroll, B.K. Kit, K.M. Flegal, Prevalence of childhood and adult obesity in the United States, 2011-2012, JAMA: J. Am. Media. 311 (2014) $806-814$.

[3] M.J. Ronis, J.N. Baumgardner, N. Sharma, J. Vantrease, M. Ferguson, Y. Tong, X. Wu, M.A. Cleves, T.M. Badger, Medium chain triglycerides dose-dependently prevent liver pathology in a rat model of non-alcoholic fatty liver disease, Exp. Biol. Med. 238 (2013) 151-162.

[4] N. Hariri, R. Gougeon, L. Thibault, A highly saturated fat-rich diet is more obesogenic than diets with lower saturated fat content, Nutr. Res. 30 (2010) 632-643 (doi: 610.1016/j.nutres.2010.1009.1003).

[5] R. Buettner, K.G. Parhofer, M. Woenckhaus, C.E. Wrede, L.A. Kunz-Schughart, J. Scholmerich, L.C. Bollheimer, Defining high-fat-diet rat models: metabolic and molecular effects of different fat types, J. Mol. Endocrinol. 36 (2006) 485-501.

[6] 2015-2020 Dietary Guidelines for Americans, 8th Edition, in, U.S. Department of Health and Human Services and U.S. Department of Agriculture, Washington, D.C., 2015.

[7] M.A. Martínez-González, J. Salas-Salvadó, R. Estruch, D. Corella, M. Fitó, E. Ros, P. Investigators, Benefits of the Mediterranean diet: insights from the PREDIMED study, Prog. Cardiovasc. Dis. 58 (2015) 50-60.

[8] A.R. Alvheim, B.E. Torstensen, Y.H. Lin, H.H. Lillefosse, E.J. Lock, L. Madsen, L. Froyland, J.R. Hibbeln, M.K. Malde, Dietary linoleic acid elevates the endocannabinoids 2-AG and anandamide and promotes weight gain in mice fed a low fat diet, Lipids 49 (2014) 59-69. http://dx.doi.org/10.1007/s11745-11013-13842-y (Epub 12013 Oct 11741).

[9] H. Bjermo, D. Iggman, J. Kullberg, I. Dahlman, L. Johansson, et al., Effects of n-6 PUFAs compared with SFAs on liver fat, lipoproteins, and inflammation in abdominal obesity: a randomized controlled trial, Am. J. Clin. Nutr. 95 (2012) 1003-1012.

[10] A.R. Alvheim, M.K. Malde, D. Osei-Hyiaman, Y.H. Lin, R.J. Pawlosky, L. Madsen, K. Kristiansen, L. Froyland, J.R. Hibbeln, Dietary linoleic acid elevates endogenous 2-AG and anandamide and induces obesity, Obesity 20 (2012) 1984-1994 (doi: 1910.1038/oby.2012.1938. Epub 2012 Feb 1915).

[11] P.C. Calder, Functional roles of fatty acids and their effects on human health, J Parent. Enter. Nutr. 15 (2015) (0148607115595980).

[12] J. Araya, R. Rodrigo, P. Pettinelli, A.V. Araya, J. Poniachik, L.A. Videla, Decreased liver fatty acid delta-6 and delta-5 desaturase activity in obese patients, Obesity 18 (2010) 1460-1463.

[13] Y. Wang, D. Botolin, J. Xu, B. Christian, E. Mitchell, et al., Regulation of hepatic fatty acid elongase and desaturase expression in diabetes and obesity, J. Lipid Res. 47 (2006) 2028-2041.

[14] M.J. Picklo Sr., J.W. Newman, Antioxidant supplementation and obesity have independent effects on hepatic oxylipin profiles in insulin-resistant, obesity-prone rats, Free Radic. Biol. Med. 89 (2015) 182-191. http://dx.doi.org/10.1016/ j.freeradbiomed.2015.1007.1152 (Epub 2015 Sep 1029).

[15] D. Grapov, S.H. Adams, T.L. Pedersen, W.T. Garvey, J.W. Newman, Type 2 diabetes associated changes in the plasma non-esterified fatty acids, oxylipins and endocannabinoids, PLoS One 7 (2012) e48852 (doi: 48810.41371/journal.pone.0048852. Epub 0042012 Nov 0048858).

[16] E. Fjaere, U.L. Aune, K. Roen, A.H. Keenan, T. Ma, et al., Indomethacin treatment prevents high fat diet-induced obesity and insulin resistance but not glucose intolerance in C57BL/6J mice, J. Biol. Chem. 289 (2014) 16032-16045.

[17] J.T. Brenna, Efficiency of conversion of alpha-linolenic acid to long chain n-3 fatty acids in man, Curr. Opin. Clin. Nutr. Metab. Care 5 (2002) 127-132.

[18] G. Barcelo-Coblijn, E.J. Murphy, Alpha-linolenic acid and its conversion to longer chain $n-3$ fatty acids: benefits for human health and a role in maintaining tissue $n-3$ fatty acid levels, Prog. Lipid Res. 48 (2009) 355-374.

[19] A.F. Domenichiello, A.P. Kitson, R.P. Bazinet, Is docosahexaenoic acid synthesis from alpha-linolenic acid sufficient to supply the adult brain?, Prog. Lipid Res. 59 (2015) 54-66. http://dx.doi.org/10.1016/j.plipres.2015.1004.1002.

[20] G. Dhopeshwarkar, J.F. Mead, Role of oleic acid in the metabolism of essential fatty acids, J. Am. Oil Chem. Soc. 38 (1961) 297-301.

[21] N.K. Menon, G.A. Dhopeshwarkar, Essential fatty acid deficiency and lipid metabolism of the developing brain, Prog. Lipid Res. 20 (1981) 129-134.

[22] S. Yamaoka, R. Urade, M. Kito, Cardiolipin molecular species in rat heart mitochondria are sensitive to essential fatty acid-deficient dietary lipids, J. Nutr. 120 (1990) 415-421. 
[23] A. Berger, M.E. Gershwin, J.B. German, Effects of various dietary fats on cardiolipin acyl composition during ontogeny of mice, Lipids 27 (1992) 605-612.

[24] M.J. Picklo, E.J. Murphy, A. High-Fat, high-oleic diet, But not a high-fat, saturated diet, reduces hepatic alpha-linolenic acid and eicosapentaenoic acid content in mice, Lipids 51 (2016) 537-547 (doi: 510.1007/s11745-11015-14106-11749. Epub 12015 Dec 11722).

[25] P.G. Reeves, F.H. Nielsen, G.C. Fahey Jr., AIN-93 purified diets for laboratory rodents: final report of the American Institute of Nutrition ad hoc writing committee on the reformulation of the AIN-76A rodent diet, J. Nutr. 123 (1993) 1939-1951.

[26] J.E. Ayala, V.T. Samuel, G.J. Morton, S. Obici, C.M. Croniger, G.I. Shulman, D.H. Wasserman, O.P. McGuinness, Standard operating procedures for describing and performing metabolic tests of glucose homeostasis in mice, Dis. Mod. Mech. 3 (2010) 525-534.

[27] E. Murphy, T. Rosenberger, L. Horrocks, Effects of maturation on the phospholipid and phospholipid fatty acid compositions in primary rat cortical astrocyte cell cultures, Neurochem. Res. 22 (1997) 1205-1213.

[28] C.A. Jolly, T. Hubbell, W.D. Behnke, F. Schroeder, Fatty acid binding protein: stimulation of microsomal phosphatidic acid formation, Arch. Biochem. Biophys. 341 (1997) 112-121.

[29] G. Rouser, A. Siakotos, S. Fleischer, Quantitative analysis of phospholipids by thinlayer chromatography and phosphorus analysis of spots, Lipids 1 (1966) 85-86.

[30] E.O. Uthus, M.J. Picklo Sr, Obesity reduces methionine sulphoxide reductase activity in visceral adipose tissue, Free Rad. Res. 45 (2011) 1052-1060.

[31] H.M. Aukema, T. Winter, A. Ravandi, S. Dalvi, D.W. Miller, G.M. Hatch, Generation of bioactive oxylipins from exogenously added arachidonic, eicosapentaenoic and docosahexaenoic acid in primary human brain microvessel endothelial cells, Lipids 51 (2016) 591-599.

[32] R. Deems, M.W. Buczynski, R. Bowers-Gentry, R. Harkewicz, E.A. Dennis, Detection and quantitation of eicosanoids via high performance liquid chromatography-electrospray ionization-mass spectrometry, Methods Enzym. 432 (2007) $59-82$.

[33] L.M. Hall, R.C. Murphy, Electrospray mass spectrometric analysis of 5-hydroperoxy and 5-hydroxyeicosatetraenoic acids generated by lipid peroxidation of red blood cell ghost phospholipids, J. Am. Soc. Mass Spectrom. 9 (1998) 527-532.

[34] W. Stillwell, L.J. Jenski, F.T. Crump, W. Ehringer, Effect of docosahexaenoic acid on mouse mitochondrial membrane properties, Lipids 32 (1997) 497-506.

[35] J.J. Peifer, R.T. Holman, Effect of saturated fat upon essential fatty acid metabolism of the rat, J. Nutr. 68 (1959) 155-168.

[36] T. Ota, C. Gayet, H.N. Ginsberg, Inhibition of apolipoprotein B100 secretion by lipid-induced hepatic endoplasmic reticulum stress in rodents, J. Clin. Invest. 118 (2008) 316-332.

[37] M. Igarashi, K. Ma, L. Chang, J.M. Bell, S.I. Rapoport, Rat heart cannot synthesize docosahexaenoic acid from circulating alpha-linolenic acid because it lacks elongase-2, J. Lipid Res. 49 (2008) 1735-1745 (1710.1194/jlr.M800093JLR800200. Epub 802008 May 80, 0091).

[38] A. Baylin, E.K. Kabagambe, X. Siles, H. Campos, Adipose tissue biomarkers of fatty acid intake, Am. J. Clin. Nutr. 76 (2002) 750-757.

[39] L. Hodson, C.M. Skeaff, B.A. Fielding, Fatty acid composition of adipose tissue and blood in humans and its use as a biomarker of dietary intake, Prog. Lipid Res. 47 (2008) 348-380 (doi: 310.1016/j.plipres.2008.1003.1003. Epub 2008 Apr 1014).

[40] N.A. Abumrad, J.H. Park, C.R. Park, Permeation of long-chain fatty acid into adipocytes. kinetics, specificity, and evidence for involvement of a membrane protein, J. Biol. Chem. 259 (1984) 8945-8953.

[41] N.A. Abumrad, P.R. Perry, R.R. Whitesell, Stimulation by epinephrine of the membrane transport of long chain fatty acid in the adipocyte, J. Biol. Chem. 260 (1985) 9969-9971.

[42] A. Ibrahimi, Z. Sfeir, H. Magharaie, E.Z. Amri, P. Grimaldi, N.A. Abumrad, Expression of the CD36 homolog (FAT) in fibroblast cells: effects on fatty acid transport, Proc. Natl. Acad. Sci. USA 93 (1996) 2646-2651.

[43] F. Nassir, B. Wilson, X. Han, R.W. Gross, N.A. Abumrad, CD36 is important for fatty acid and cholesterol uptake by the proximal but not distal intestine, J. Biol. Chem. 282 (2007) 19493-19501 (Epub 12007 May 1, 9415).
[44] S.P. Caligiuri, K. Love, T. Winter, J. Gauthier, C.G. Taylor, T. Blydt-Hansen, P. Zahradka, H.M. Aukema, Dietary linoleic acid and alpha-linolenic acid differentially affect renal oxylipins and phospholipid fatty acids in diet-induced obese rats, J. Nutr. 143 (2013) 1421-1431.

[45] A. Nishiokada, M. Miyoshi, M. Fujiwara, M. Aoyama-Ishikawa, N. Maeshige, et al., Changes of hepatic lipid mediators associated with intake of high-fat diet for 12 weeks in endotoxemic rats using LC-ESI-MS/MS, Clin. Nutr. 34 (2014) 685-693.

[46] D. Maciejewska, P. Ossowski, A. Drozd, K. Ryterska, D. Jamiol-Milc, et al., Metabolites of arachidonic acid and linoleic acid in early stages of non-alcoholic fatty liver disease - a pilot study, Prostaglandins Other Lipid Mediat 121 (2015) 184-189 (doi: 110.1016/j.prostaglandins.2015.1009.1003. Epub 2015 Sep 1025).

[47] G.C. Shearer, J.W. Newman, Lipoprotein lipase releases esterified oxylipins from very low-density lipoproteins, Prostaglandins Leukot. Ess. Fat. Acids 79 (2008) 215-222 (doi: 210.1016/j.plefa.2008.1009.1023. Epub 2008 Nov 1029).

[48] E.P. Brass, M.J. Garrity, Structural specificity for prostaglandin effects on hepatocyte glycogenolysis, Biochem. J. 267 (1990) 59-62.

[49] A.M. Gomez-Foix, J.E. Rodriguez-Gil, J.J. Guinovart, F. Bosch, Prostaglandins E2 and F2 alpha affect glycogen synthase and phosphorylase in isolated hepatocytes, Biochem. J. 261 (1989) 93-97.

[50] U. Hespeling, K. Jungermann, G.P. Puschel, Feedback-inhibition of glucagonstimulated glycogenolysis in hepatocyte/Kupffer cell cocultures by glucagon-elicited prostaglandin production in Kupffer cells, Hepatology 22 (1995) 1577-1583.

[51] F. Neuschafer-Rube, G.P. Puschel, K. Jungermann, Characterization of prostaglandin-F2 alpha-binding sites on rat hepatocyte plasma membranes, Eur. J. Biochem. 211 (1993) 163-169.

[52] A. Ocklind, S. Lake, K. Krook, I. Hallin, M. Nister, B. Westermark, Localization of the prostaglandin F2 alpha receptor in rat tissues, Prostaglandins Leukot. Ess. Fat. Acids 57 (1997) 527-532.

[53] V.A. Fajardo, L. McMeekin, C. Saint, P.J. LeBlanc, Cardiolipin linoleic acid content and mitochondrial cytochrome c oxidase activity are associated in rat skeletal muscle, Chem. Phys. Lipids 187 (2015) 50-55. http://dx.doi.org/10.1016/ j.chemphyslip.2015.1002.1004 (Epub 2015 Feb 1026).

[54] G.P. Holloway, V.A. Fajardo, L. McMeekin, P.J. LeBlanc, Unsaturation of mitochondrial membrane lipids is related to palmitate oxidation in subsarcolemmal and intermyofibrillar mitochondria, J. Membr. Biol. 245 (2012) 165-176 (doi: 110.1007/s00232-00012-09426-00236. Epub 02012 Apr 00218).

[55] J.M. Caviglia, C. Gayet, T. Ota, A. Hernandez-Ono, D.M. Conlon, H. Jiang, E.A. Fisher, H.N. Ginsberg, Different fatty acids inhibit apoB100 secretion by different pathways: unique roles for ER stress, ceramide, and autophagy, J. Lipid Res. 52 (2011) 1636-1651 (doi: 1610.1194/jlr.M016931. Epub 012011 Jun 016930).

[56] S.J. Wakil, L.A. Abu-Elheiga, Fatty acid metabolism: target for metabolic syndrome, J. Lipid Res. 50 (2009) S138-S143 (doi: 110.1194/jlr.R800079JLR800200. Epub 802008 Dec 800071).

[57] C. Bourque, M.P. St-Onge, A.A. Papamandjaris, J.S. Cohn, P.J. Jones, Consumption of an oil composed of medium chain triacyglycerols, phytosterols, and n-3 fatty acids improves cardiovascular risk profile in overweight women, Metabolism 52 (2003) 771-777.

[58] L. Eyres, M.F. Eyres, A. Chisholm, R.C. Brown, Coconut oil consumption and cardiovascular risk factors in humans, Nutr. Rev. 74 (2016) 267-280 (doi: 210.1093/nutrit/nuw1002. Epub 2016 Mar 1095).

[59] What We Eat in America 2013-2014 National Health and Nutrition Examination Survey. NHANES 2013-2014, in, Centers for Disease Control and Prevention; National Center for Health Statistics, 〈https://www.ars.usda.gov/ARSUserFiles/ 80400530/pdf/1314/Table_1_NIN_GEN_13.pdf .

[60] Oilseeds: World markets and trade, in, United States Department of Agriculture, Foreign Agricultural Service, 2015.

[61] P.J. Huth, V.L. Fulgoni 3rd, B.T. Larson, A systematic review of high-oleic vegetable, oil substitutions for other fats and oils on cardiovascular disease risk factors: implications for novel high-oleic soybean oils, Adv. Nutr. 6 (2015) 674-693 (doi: 610.3945/an.3115.008979. Print 002015 Nov). 